\title{
EFFECTS OF ALDERS (ALNUS SP.) USED FOR RECLAMATION OF LIGNITE COMBUSTION WASTES ${ }^{1}$
}

\author{
Marcin Pietrzykowski², Bartłomiej Woś, Marcin Chodak, Katarzyna Sroka, Marek Pająk, \\ Tomasz Wanic and Wojciech Krzaklewski
}

\begin{abstract}
Combustion waste and fly ash disposal sites have unfavourable properties for revegetation. Owing to its phytoameliorative ability different alder species have long been used in the reclamation of degraded sites, as $\mathrm{N}$-fixing species and forecrop for introducing more demanding tree species in reforestation. We present the growth parameters and effects of black alder (Alnus glutinosa), grey alder (A. incana), and green alder (A. viridis) on the physicochemical and biological properties of the technosols developed from the lignite combustion wastes disposal site in central Poland after 10 years of plant growth. The study plots were randomly arranged ( $72 \mathrm{~m}^{2}$ of each plot, four replications for variant) at 3 species $\times 2$ different soil treatments: $\mathrm{CCW}+\mathrm{L}$ (combustion waste with lignite amendment in planting hole) and CCW (pure combustion waste). The obtained results indicate that soil treatment did not significantly influence the studied physicochemical soil parameters ( $\mathrm{pH}, \mathrm{CEC}, \mathrm{RESP}, \mathrm{SOC}, \mathrm{N}_{\text {tot }}$ and macronutrients content) either in $\mathrm{O}$ horizon or in the mineral soil. The effect of species on $\mathrm{pH}, \mathrm{N}_{\text {tot }}$ and macronutrients content was evident in the $\mathrm{O}$ horizon but not in the mineral soil. The better growth parameters were found for black alder than for grey alder. The mean height was 3.9 and $6.3 \mathrm{~m}$ for grey and black alder, respectively. Accumulation of litter layer $\left(\mathrm{O}_{1}\right)$ ranged from 2.9 to $3.6 \mathrm{Mg} \mathrm{ha}^{-1}$ (mega gram per hectare), and grey alder litter was characterized by the highest content of nutrients (N-P-K). Organic C content in the $0-5 \mathrm{~cm}$ mineral layer (A) increased to 38.06 and $47.80 \mathrm{~g} \mathrm{~kg}^{-1}$ ( $\mathrm{gram}$ per kilogram dry soil), respectively for green and black alder. The highest $\mathrm{N}$ content in A layer was measured under black alder. Microbial respiration and biomass were significantly lower in the $\mathrm{O}_{1}$ layer under green alder than under two other alder species. However, in the mineral soil all three alder species stimulated microbialbiomass and activity similarly. Because of the highest growth parameters of black alder and the highest litter production under canopy and $\mathrm{N}$ content in the soil we recommend this species for revegetation of combustion waste disposal site.
\end{abstract}

Additional Key Words: Fly ash, revegetation, N-fixing, soil respiration

\footnotetext{
${ }^{1}$ Paper presented at the 2018 National Meeting of the American Society of Mining and Reclamation, St. Louis, MO: The Gateway to Land Reclamation, June 3 - 7, 2018. Published by ASMR; 1305 Weathervane Dr., Champaign, IL61821.

${ }^{2}$ Marcin Pietrzykowski, Professor, Department of Forest Ecology and Reclamation, Institute of Ecology and Silviculture, Faculty of Forestry, University of Agriculture in Krakow, Al. 29 Listopada 46, 31-425 Krakow, Poland.
}

Journal American Society of Mining and Reclamation, 2018 Volume 7, Issue 1 pp 30-55

DOI: http://doi.org/10.21000/JASMR18010030 


\section{Introduction}

Combustion waste disposal sites adversely affect the environment in adjacent areas because of wind erosion and dust pollution as well as due to alkaline leachate and saline water which frequently contain heavy metals resulting in ground water contamination (Haynes, 2009). Ash and dust from combustion waste landfills remain suspended in the air for a long time and may negatively affect the adjacent ecosystems by soil pollution and alkalization and even the health of the local population (Dellantonio et al., 2009; Pandey et al., 2009). Biological containment of combustion waste disposal sites by planting shrubs and trees on their slopes and tops is an effective method of limiting wind erosion and other adverse effects they might produce (Pandey and Singh, 2012; Pandey, 2015; Żołnierz et al., 2016). However, introduction of vegetation on combustion waste may be difficult due to negative physicochemical properties of these materials such as high susceptibility to compaction, poor air to water ratios, excessively alkaline reaction, high EC variability, lack of nitrogen and available phosphorus, and in some cases, high content of heavy metals (Adriano et al., 1980; Haynes, 2009; Krzaklewski et al., 2012; Pietrzykowski et al., 2015).

Nevertheless, several plant species proved to be useful in revegetation of combustion waste disposal sites. These included some members of Leguminosae, Chenopodiaceae, Cruciferae and Gramineae families (Haynes, 2009). In addition, N-fixing trees and shrubs such as black alder (Alnus glutinosa), silver berry (Elaeagnus commutata), bladder senna (Colutea arborescens), common sea-buckthorn (Hippophae rhamnoides), and honey locust (Gleditsia triacanthos) have been described as tolerant to the conditions of fly ash land fills (Hodgson and Townsend 1973). Sweet gum (Liquidambar styraciflua) and American sycamore (Platanus occidentalis) grew acceptably on a basin of bottom ash from a coal-fired boiler (Carlson and Adriano 1991). However, in several studies on the revegetation of combustion waste disposal sites the ashes were covered with a layer of mineral soil (Čermák, 2008; Pietrzykowski et al., 2010). This practice is expensive and entails the risk of root system deformation as the roots develop primarily in the surface horizons containing mineral soil (Čermák, 2008).

Alders (Alnus sp.) are promising plants for land reclamation and biological restoration of combustion waste disposal sites (Čermák, 2008; Krzaklewski et al., 2012; Pietrzykowski et al., 2015). They often quickly appear on abandoned arable fields and burned forests in the first stages of secondary succession (Mitchell and Ruess, 2009). However, they do not naturally colonize post-mining barrens or fly ash disposal sites - probably due to disadvantageous environmental 
conditions on these sites. Therefore, alders need to be planted during the reclamation process. The symbiosis with nodule forming bacteria capable of atmospheric $\mathrm{N}$ fixation makes them valuable in the reclamation of post-industrial barrens (Krzaklewski et al., 2012). Due to litterfall and intensive rooting, alders increase the amount of soil organic matter (SOM) and the bioavailability of nutrients, acting as a natural "fertilizer" in former industrial sites (Šourková et al., 2005). Different alder species have been used in the reclamation of former industrial sites in a wide range of conditions and soil substrates (Frouz et al., 2001; Krzaklewski et al., 2003; Šourková et al., 2005; Lõhmus et al., 2007; Kuznetsova et al., 2011; Józefowska et al., 2016). If the impact of alders transformed combustion waste technogenic soil substrates, which are extremely difficult to reclaim, they could even adopt ecological functions of soil. This would solve the problem of biological stabilization and reclaim hundreds of thousands of hectares of combustion waste disposal site in the northern hemisphere, where alders are in natural distribution.

Black alder was considered a species that displays good growth parameters in combustion waste sedimentation ponds covered with $0.4-0.5 \mathrm{~m}$ layer of mineral soil (Čermák, 2008). However, trials of the introduction of black and grey alder directly onto a sedimentation pond for ashes from bituminous coal combustion in Halemba power plant (southern Poland) and in a lignite power plant in Konin (central Poland) carried out in the 1970s were less successful and indicated low survival rate and poor growth of the introduced alder species (Wysocki, 1979). Only recently, Krzaklewski et al. (2012) suggested that black and grey alder, can be successfully used in the biological restoration of lignite combustion waste disposal sites and Pietrzykowski et al. (2015) pointed out that green alder (Alnus viridis) may also be a prospective species for biological reclamation and anti-erosion protection. Large scale application of alder species for reclamation of ash deposition sites requires detailed knowledge on the survival, growth rate, and influence on soil substrate of individual alder species and determination of optimal time for alder growth as a fore crop and its replacement with target species.

The objectives of this work were: 1) to compare the growth parameters (stand density, survival, height, diameter at breast height, current annual growth of tree height) of alders (Alnusglutinosa (L.) GAERTN.,A. incana (L.) MOENCH, and A. viridis (Chaix) DC), 2) to assess their influence on the properties of combustion waste technosols after 10 years of growth, and 3) to test whether lignite addition to planting holes may improve the growth of alders on the combustion wastes. 


\section{Materials and methods}

$\underline{\text { Study site }}$

Lubień combustion waste disposal site is located in Central Poland (N 51 27; E 19 27), in a temperate climate zone with precipitation ranging from 550 to $600 \mathrm{~mm}$ annually and an average annual temperature of around $7.6-8.0^{\circ} \mathrm{C}$. The vegetation period lasts from 210 to 218 days (Woś, 1999). The Lubień disposal site has been in operation since 1980 and currently occupies ca. 440 ha. Combustion waste containing about $85 \%$ ash and $15 \%$ slag is deposited there by hydrotransport (Fig 1). The main component of combustion waste is thermally processed aluminosilicates. The average content of $\mathrm{Al}_{2} \mathrm{O}_{3}$ and $\mathrm{SiO}_{2}$ compounds is from about 60 to $70 \%$, and $\mathrm{CaO}$ about $20 \%$. The content of trace elements generally does not exceed the average reported for natural soils. In the case of the Lubien disposal site, adverse environmental impact is caused mainly by leaching of $\mathrm{SO}_{4}{ }^{2-}, \mathrm{Cl}$, and $\mathrm{Ca}$, which in turn increases the concentrations of these ions, overall hardness, and alkalinization of ground water (Krzaklewski et al., 2012).

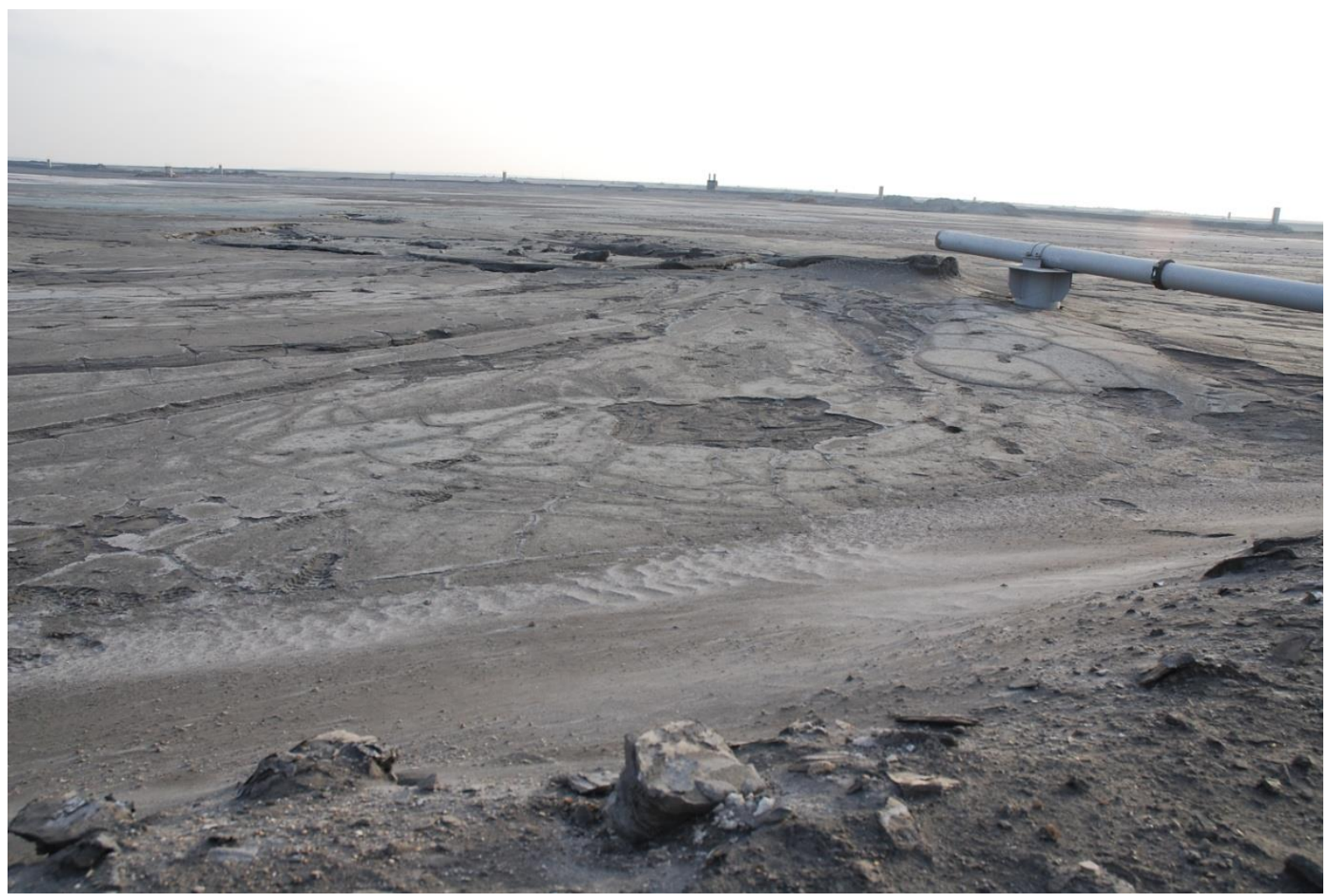

Figure 1. General view on flat top of Lubień lignite combustion waste disposal site (central Poland, $\left.51^{\circ} 27^{\prime} 34^{\prime \prime} \mathrm{N} ; 1^{\circ} 26^{\prime} 50^{\prime \prime}\right)$. Photo by M. Pietrzykowski. 


\section{Description of the experiment}

The experiment started in September 2005 in a part of a sedimentation tank flat shelf set up between 2003 and 2004. Before the start of the experiment and the planting of trees on the entire surface, it was first subject to hydro-seeding with biosolids (sewage sludge of $4 \mathrm{Mg}$ dry mass ha ${ }^{-1}$ ) mixed with the seeds $\left(200 \mathrm{~kg} \mathrm{ha}^{-1}\right)$ of Cock's-foot grass (Dactylis glomerata L.) and Italian ryegrass (Lolium multiflorum Lam.). Next, NPK start-up mineral fertilizing was applied with N $60, \mathrm{P}-36$ and $\mathrm{K}-36 \mathrm{~kg} \mathrm{ha}^{-1}$. The experimental area was divided into 24 plots ( $\left.6 \mathrm{~m} \times 13 \mathrm{~m} \mathrm{each}\right)$, separated by a $2-$ metre-wide buffer strip (not planted and covered by grasses). The plots were randomly assigned a species and soil treatment $(3 \times 2)$ in 4 replications. Within each plot, 50 individuals of each species were planted. A total of 1200 individuals were planted for the entire experiment. Seedlings of black, grey and green alder were planted on the plots in holes (Fig 2) of $40 \mathrm{~cm} \times 40 \mathrm{~cm} \times 40 \mathrm{~cm}$ in 2 soil treatment variants (with 4 replications for each variant): lignite addition (CFA + L) and control without any soil amendment (CFA) in planting holes (Krzaklewski et al., 2012). The application of lignite culm into the planting holes was intended to improve the growth of trees on highly alkaline combustion waste. The results of the survival and growth assessment of the alders after 5 years were published by Krzaklewski et al. (2012) and Pietrzykowski et al. (2015).

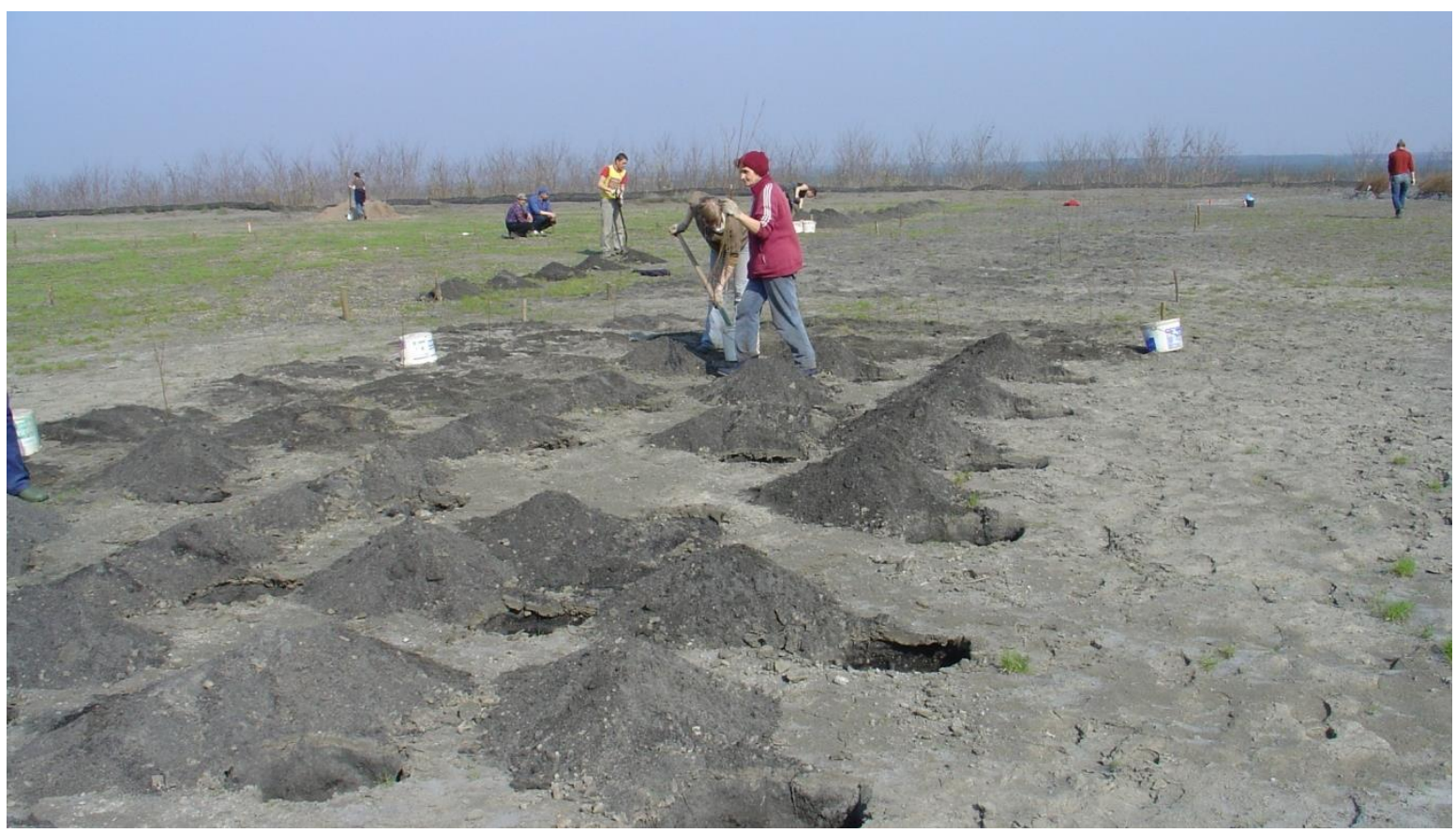

Figure 2. Preparation of surface and bore holes for alder seedlings with improvement by lignite culm addition, early spring 2006. Photo by W. Krzaklewski. 


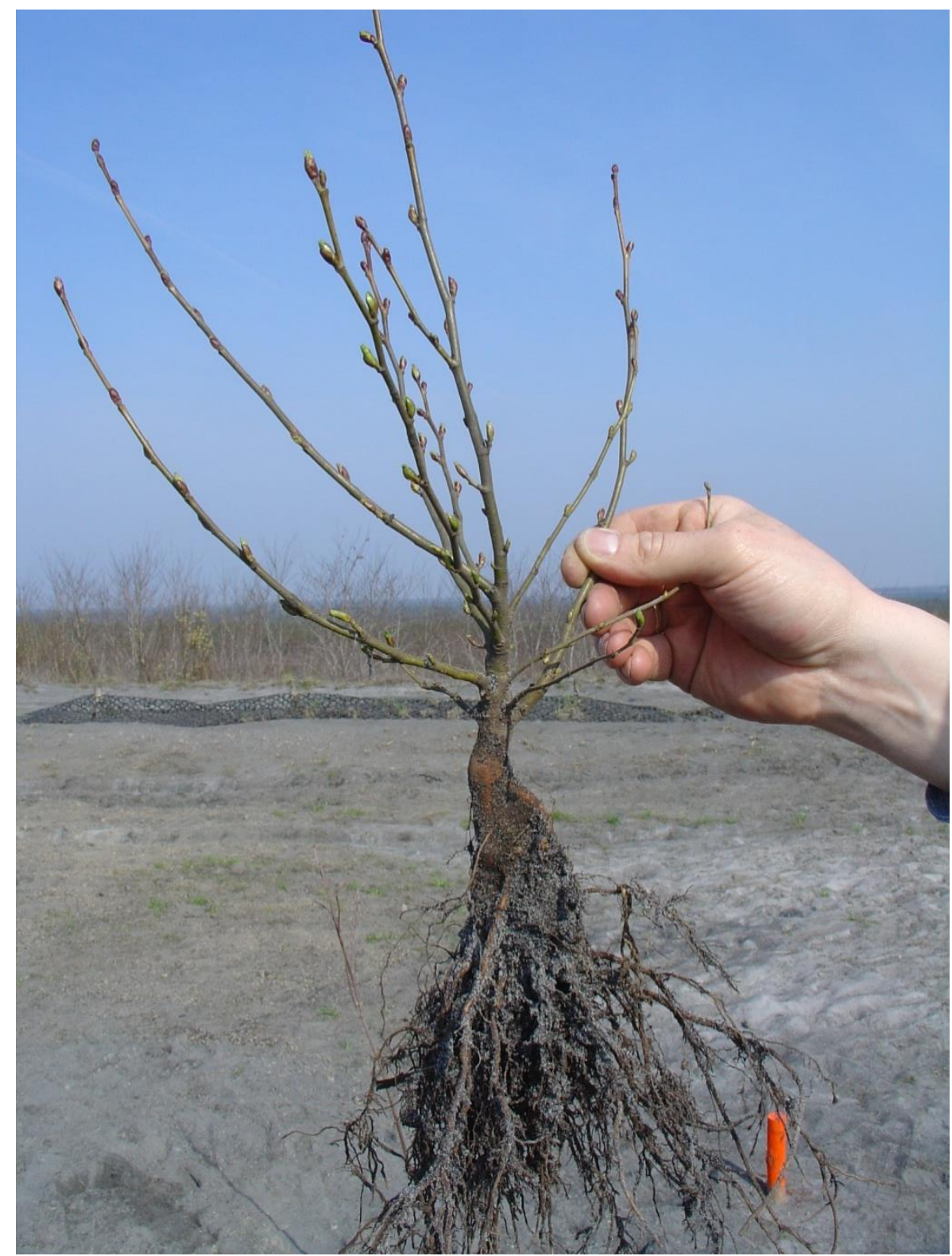

Figure 3. Green alder (Alnus viridis) seedling prepared for field experiment on lignite combustion disposal site. Photo by W. Krzaklewski.

\section{$\underline{\text { Soil sampling }}$}

The samples of organic horizon (litter $\mathrm{O}_{1}$ ) and uppermost part of the mineral soil (depth $0-5$ $\mathrm{cm}$ ) were collected in 2016. Each sample of $\mathrm{O}_{1}$ horizon or the mineral soil representative of a sampling plot, consisted of five subsamples taken at 5 points regularly distributed along the diagonal of that plot. The subsamples of $\mathrm{O}_{1}$ horizon were collected from $1.0 \mathrm{~m} \times 1.0 \mathrm{~m}$ squares and, the subsamples of the mineral soil from $25 \mathrm{~cm} \times 25 \mathrm{~cm}$ taken with the spade. In total 24 mixed samples of technosols (1.0 kg mass of fresh sample) and 24 mixed samples of $\mathrm{O}$ horizons were taken to determine soil properties in the lab. Additionally, a mixed sample of freshly deposited 
combustion waste was collected in the area nearby the experimental site. Subsequently, each organic sample horizon was weighed in the fresh state to an accuracy of $0.01 \mathrm{~kg}$ on electronic scales and then the samples were combined to produce collective samples (1.0 kg fresh weight) representative of each study site. The mineral and organic horizon samples were divided into two parts. One part was air-dried and used for physicochemical analyses, and the other one was stored field-moist at $4{ }^{\circ} \mathrm{C}$ and used for microbial and biochemical analyses.

\section{$\underline{\text { Assessment of tree growth parameters }}$}

In the black and grey alder study plot, the survival of trees and stand density (D - number of trees per ha) was assayed; diameter at breast height $(\mathrm{DBH})$ with an accuracy of $0.1 \mathrm{~cm}$ and height (H) of all trees with an accuracy of $0.01 \mathrm{~m}$ were measured. Tree measurements were conducted in the autumn 2015 after 10 years of growth. Based on these measurements and results from previous measurements in spring 2011 (Krzaklewski et al., 2012), the current annual growth was calculated for tree height $(\Delta \mathrm{H})$ from spring 2011 to autumn 2015. In addition, the upper height (H100) was determined, i.e., the average height of 100 tallest trees per hectare, and Reineke's stand density index (SDI) from the equation (Zeide, 2005):

$$
S D I=D \cdot\left(\frac{D B H}{25}\right)^{1.6}
$$

where:

SDI - stand density index;

$\mathrm{D}$ - density (number of trees per hectare);

$\mathrm{DBH}$ - diameter at breast height.

\section{$\underline{\text { Soil analyses }}$}

Soil and litter analysis were performed in the Laboratory of Geochemistry and Reclaimed Areas, Department of Forest Ecology and Reclamation according to Ostrowska et al. (1991) and van Reeuwijk (2002) procedures. Soil samples were dried and sieved through a $2.0 \mathrm{~mm}$ sieve. The basic soil parameters were determined in the soil samples: particle size using Fritsch GmbH Laser Particle Sizer ANALYSETTE 22; $\mathrm{pH}$ potentiometrically in $\mathrm{H}_{2} \mathrm{O}$ and $1 \mathrm{M} \mathrm{KCl}$ at a 1:2.5 soil : solution ratio; electrical conductivity (EC) by conductometric methods at a 1:5 soil : solution ratio at $21^{\circ} \mathrm{C}$; soil organic carbon (SOC); and total nitrogen $\left(\mathrm{N}_{\text {tot }}\right)$ content using LECO TruMac ( CNS analyser. Soil samples before the carbon analysis were treated with $10 \% \mathrm{HCl}$ to remove 
carbonates. Exchangeable acidity $(\mathrm{Hh})$ was determined in $1 \mathrm{M} \mathrm{Ca}(\mathrm{OAc})_{2}$; basic exchangeable cations $\left(\mathrm{Ca}^{2+}, \mathrm{Mg}^{2+}, \mathrm{K}^{+}, \mathrm{Na}^{+}\right)$in $1 \mathrm{M} \mathrm{NH}_{4} \mathrm{Ac}$ by ICP-OES (iCAPTM 6000 Series); CEC was determined by the sum of exchangeable cations and exchangeable acidity (Hh); and phosphorus $\left(\mathrm{P}_{\mathrm{av}}\right)$ in a form available to plants was assayed in calcium lactate extract $\left(\left(\mathrm{CH}_{3} \mathrm{CHOHCOO}\right)_{2} \mathrm{Ca}\right)$ acidified with hydrochloric acid to $\mathrm{pH} 3.6$ (according to the Egner-Riehm method) by Varian CARY 300 Conc UV-Visible Spectrophotometer. In order to calculate the content of organic carbon and $\mathrm{N}_{\text {tot }}$ accumulated in soil substrates under the impact of alder species, carbon determined in the sample of freshly deposited ash was subtracted from the carbon content in the samples collected from alder plots. It was assumed that carbon content in the samples of freshly deposited substrates equalled the amount of carbon unburnt in the combustion process in the power plant (Klotz et al., 2004).

In the litter samples, $\mathrm{pH}$ was determined potentiometrically in $\mathrm{H}_{2} \mathrm{O}$ and $1 \mathrm{M} \mathrm{KCl}$ at a 1:5 soil : solution ratio; carbon $(\mathrm{C})$ and nitrogen $(\mathrm{N})$ content using LECO TruMac® CNS analyser. Total $\mathrm{Ca}, \mathrm{Mg}, \mathrm{K}$, Na was determined by digestion in a mixture of $\mathrm{HNO}_{3}(\mathrm{~d}=1.40)$ and $60 \% \mathrm{HClO}_{4}$ acid in a 4:1 ratio; element levels were determined by atomic absorption spectroscopy ICP-OES (iCAPTM 6000 Series). Total phosphorus (P) was determined by photocolorimetry by the molybdate blue method from a $60 \% \mathrm{HClO}_{4}$ extract by Varian CARY 300 Conc UV-Visible Spectrophotometer.

To measure basal respiration (RESP) and microbial biomass $\left(\mathrm{C}_{\mathrm{mic}}\right)$ the samples $\left(5 \mathrm{~g} \mathrm{~d} . \mathrm{w}\right.$. for $\mathrm{O}_{1}$ horizon and $50 \mathrm{~g}$ d.w. for mineral soils) unamended for RESP measurements and amended with 8 mg glucose monohydrate for $\mathrm{C}_{\text {mic }}$ measurements were incubated at $22^{\circ} \mathrm{C}$ in gas-tight jars. The incubation time was 24 hours for determination of RESP and 4 hours for $\mathrm{C}_{\text {mic. }}$. The jars contained small beakers with $5 \mathrm{ml} 0.2 \mathrm{M} \mathrm{NaOH}$ to trap the evolved $\mathrm{CO}_{2}$. After the jars were opened, $2 \mathrm{ml}$ $0.9 \mathrm{M} \mathrm{BaCl}_{2}$ was added to the $\mathrm{NaOH}$; the excess of hydroxide was titrated with $0.1 \mathrm{M} \mathrm{HCl}$ in the presence of phenolphthalein as indicator. $\mathrm{C}_{\text {mic }}$ was calculated from the substrate-induced respiration rate according to the equation: $\mathrm{C}_{\text {mic }}\left[\mathrm{mg} \mathrm{g}^{-1}\right]=40.04 \mathrm{y}+0.37$, where $\mathrm{y}$ is $\mathrm{ml} \mathrm{CO}_{2} \mathrm{~h}^{1} \mathrm{~g}^{1}$.

\section{$\underline{\text { Statistical analyses }}$}

The experimental design was a completely randomised 2-way factorial (alder species and soil treatment in planting holes: $\mathrm{Sp} \times \mathrm{Tr}$ ). Data sets were first tested for normality using KolmogorovSmirnov test and for variance homogeneity using Leven's test. The effects of ST and AS 
(treatment vs. tree species) on alder growth and soil parameters were analysed by 2-way ANOVA for the majority of response variables. Tukey's honestly significant differences (HSD) test for unequal sample sizes was run if any significant differences were found $(\mathrm{p}<0.05)$. The statistical analyses applied STATISTICA version 12 software (StatSoft Inc., 1984-2017).

\section{$\underline{\text { Results and Discussion }}$}

\section{Tree growth and stand parameters}

After 10 years of growth, black alder displayed better growth parameters compared to grey alder. Differences were statistically significant for SDI, DBH, $\mathrm{H}$, and $\Delta \mathrm{H}$ (Table 1). Poorer growth parameters of grey alder might have been due to its ecological properties. In Central European conditions grey alder is smaller in size compared to black alder (Boratyński, 1980). However, when compared to their size in natural habitats both species displayed good growth parameters indicating their good adaptability. In optimal forest habitats in southern Poland black alder aged from 5-9 years displayed D - 3900-5200 trees ha ${ }^{-1}$, DBH - 2.7-4.9 cm, HL - 4.0-8.0 m (Orzeł et al., 2005). Grey alder stands in the Baltic states (Estonia) displayed the following parameters at the age of 10-12: D - 6266-15900 trees ha-1 ${ }^{-1}$ DBH - 3.7-4.6 cm, H - 5.9-8.3 m (Uri et al., 2014).

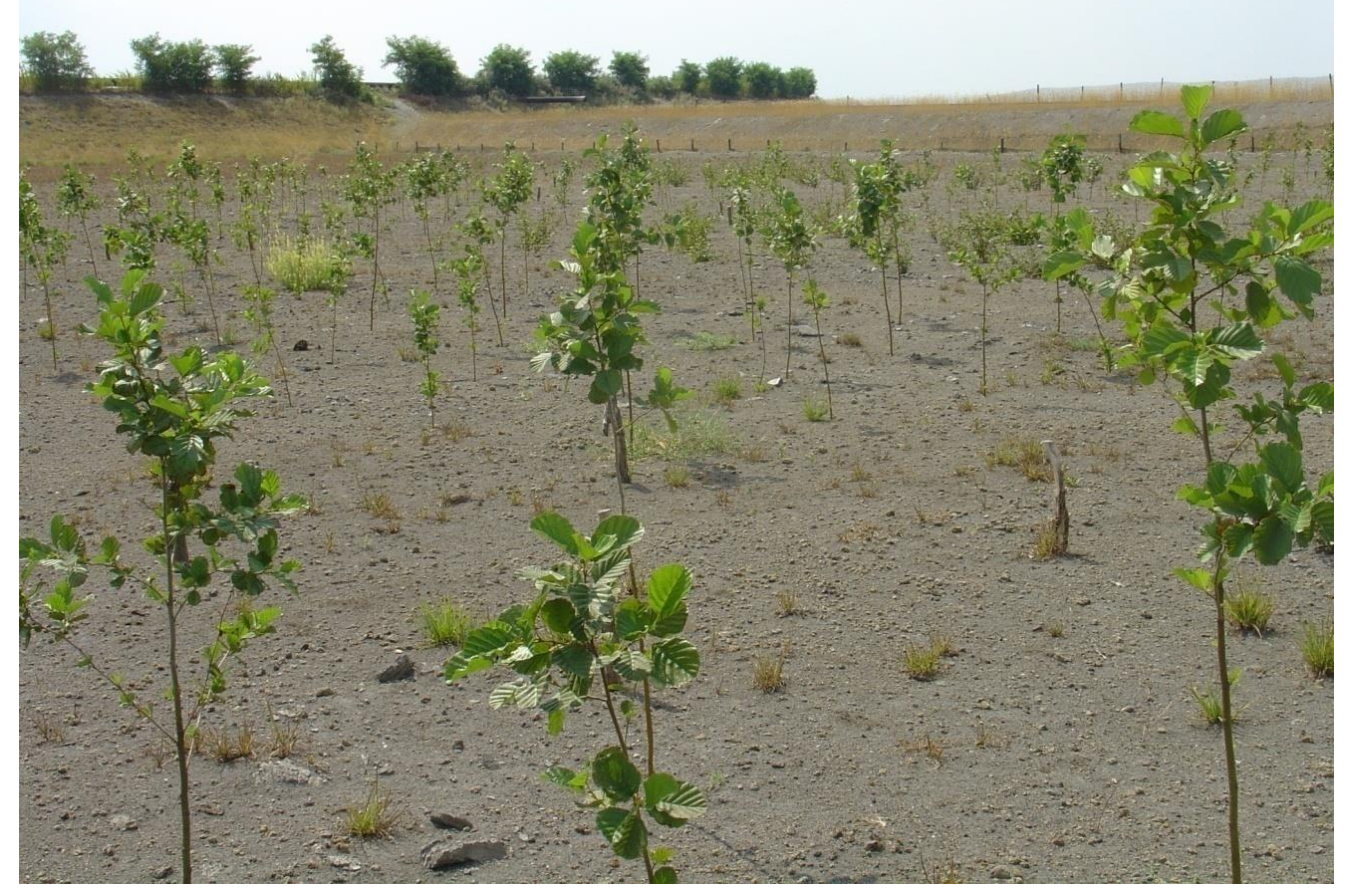

Figure 4. First year of alder growth - late spring 2006. Photo by W. Krzaklewski. 
Journal American Society of Mining and Reclamation, 2018 Vol.7, No.1

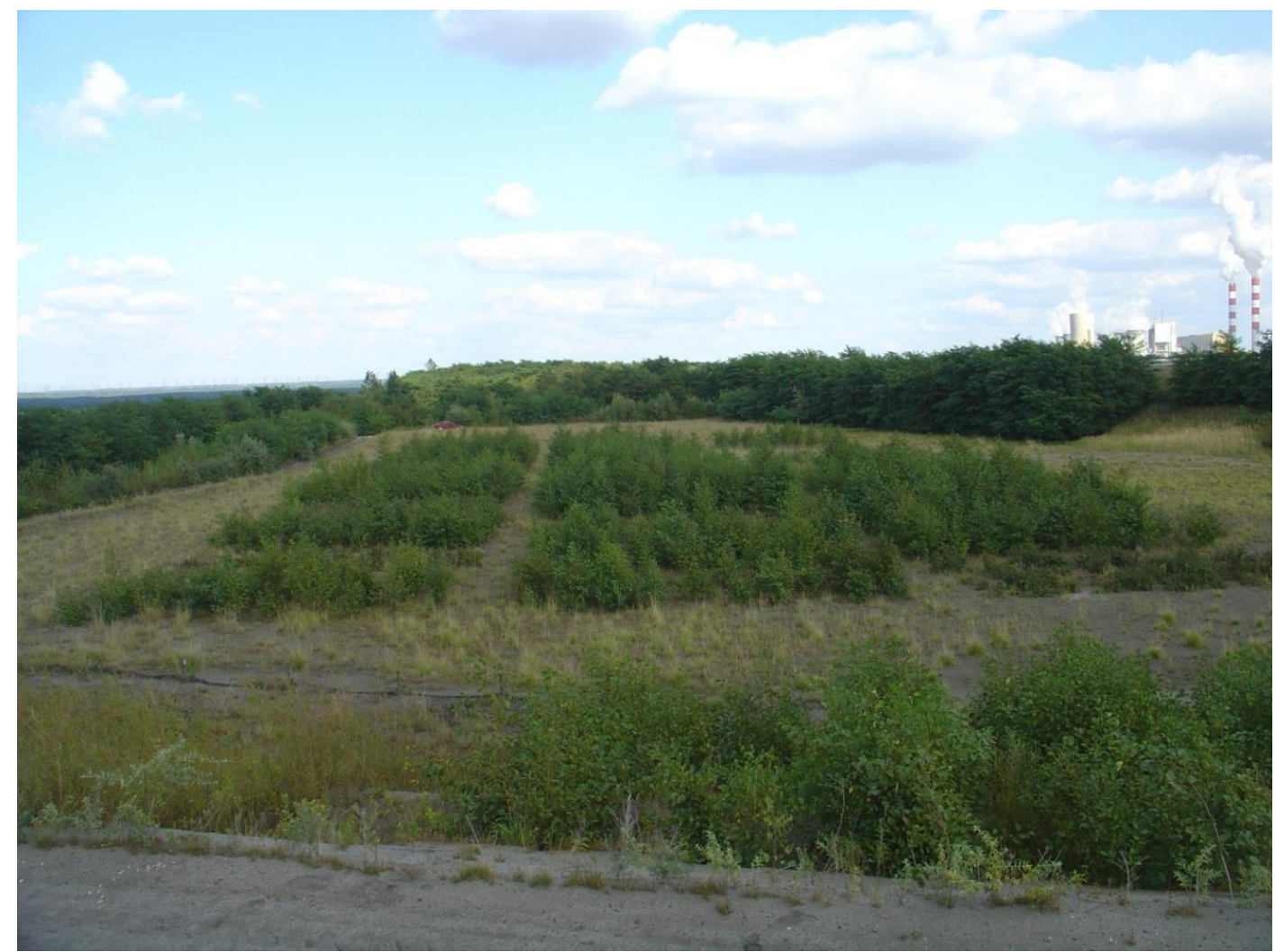

Figure 5. General view on the field experiment with alders on lignite combustion disposal sitespring 2009. Photo by W. Krzaklewski.

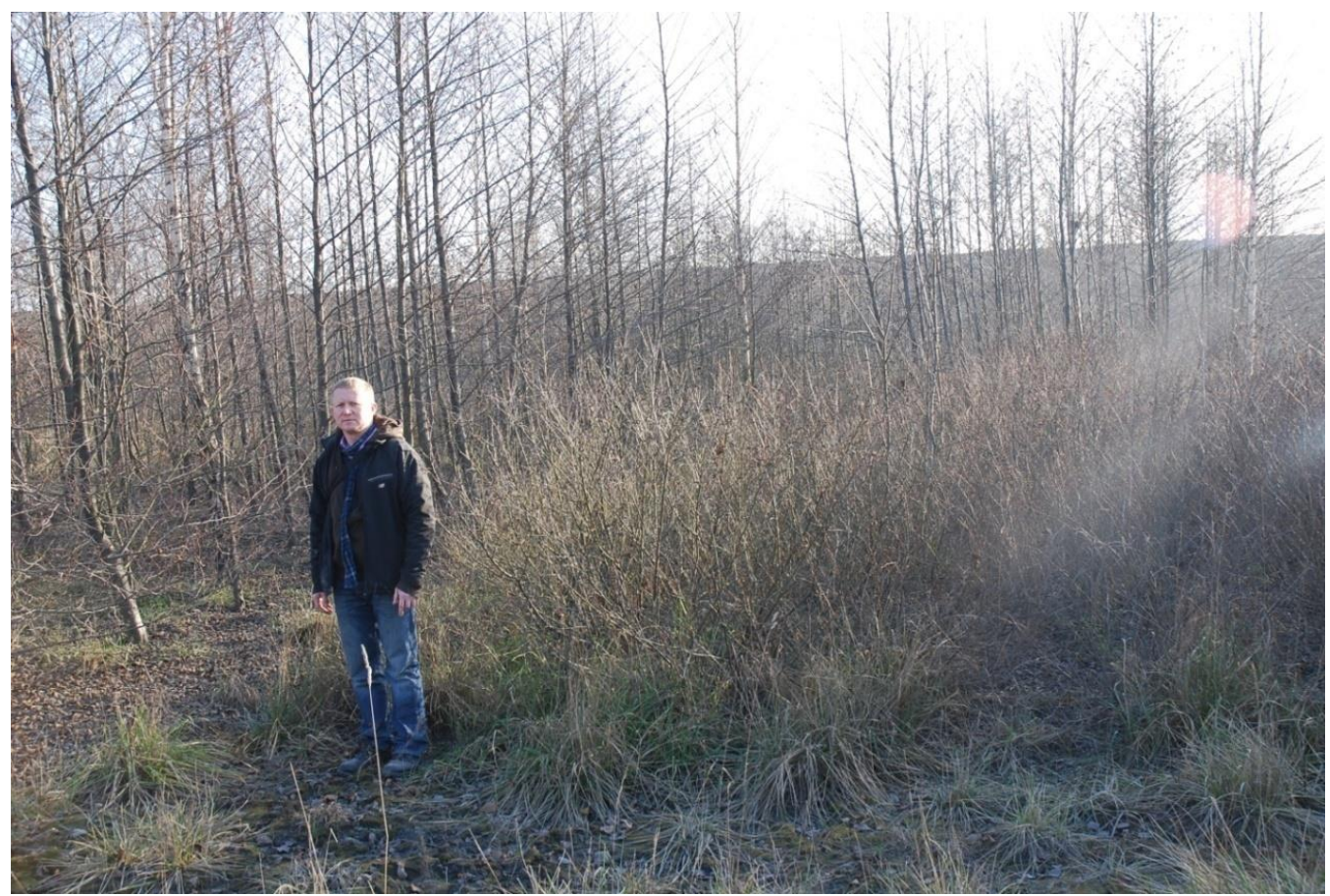

Figure 6. Green alder (shrub form on the right side) and black alder trees (left side) growing on combustion waste disposal site in the field experiment (spring 2015, nine years of growing). Photo by D. Leńczuk. 


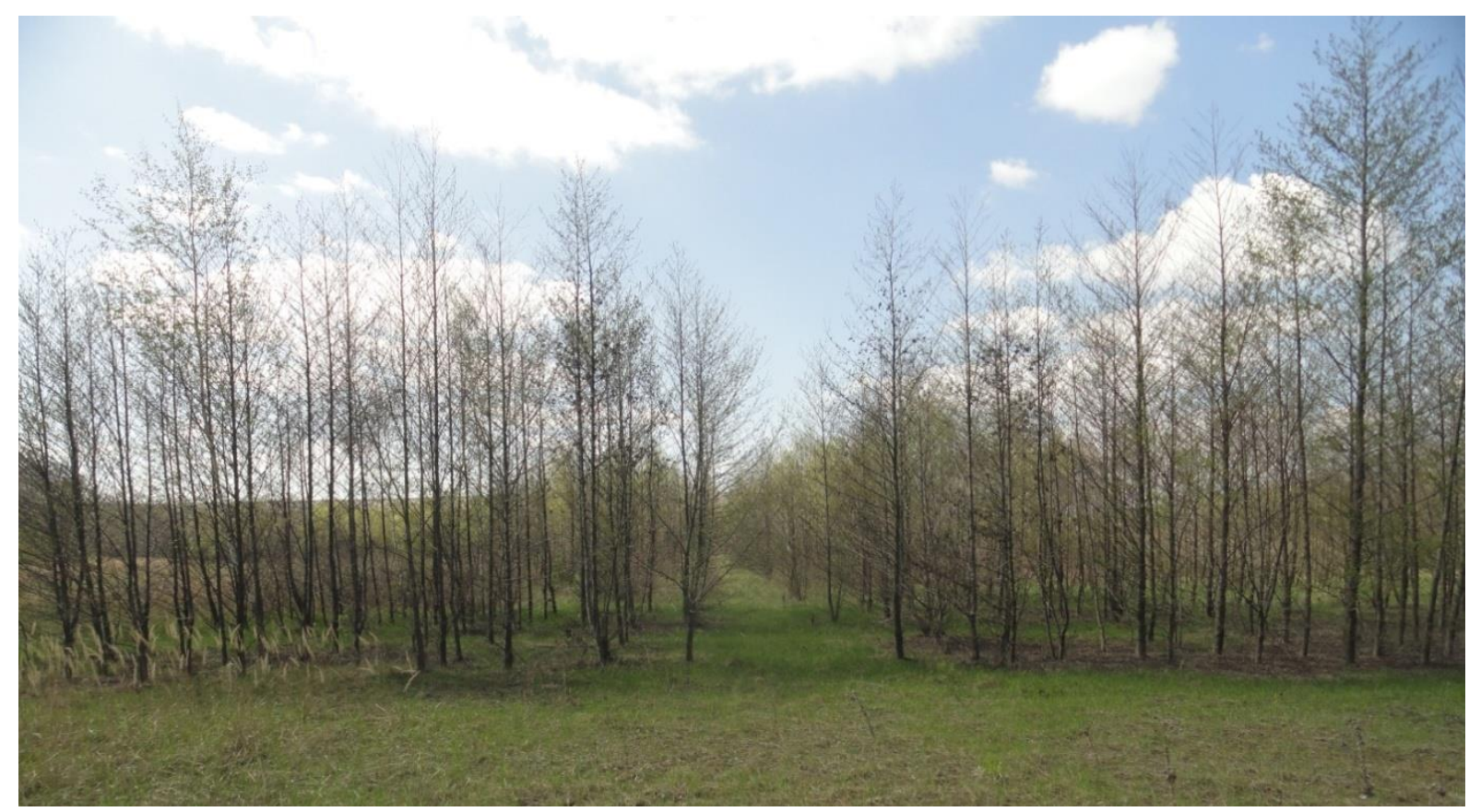

Figure 7. Black alders on combustion waste disposal site (spring 2015, nine years of growing). Photo by W. Krzaklewski.

Few differences in growth parameters of black and grey alders were found between the amendment variants used. Only the SDI index and $\mathrm{H}$ after 10 years were higher in $\mathrm{CCW}+\mathrm{L}$ while the other parameters did not differ between the tested variants (Table 1). This indicates that mineral fertilisation with NPK at the onset and stabilisation by hydro-seeding with sewage sludge and a mixture of grass seeds is sufficient to initiate the growth of alder plantings. However, for the best results, the use of lignite admixture would be recommended as tree height is widely used as an indicator of habitat fertility (Socha, 2008), while the SDI index provides information about the potential number of trees with trunk diameter of $25.4 \mathrm{~cm}$ growing in a given area (Zeide, 2005). In earlier study Krzaklewski et al. (2012) after 5 years of growth also pointed out that the best way to improve the properties of ashes for alder growth and biomass production, was to add lignite into the planting holes.

However, in harsh habitat conditions occurring in combustion waste disposal sites, maximising the growth of the introduced alder species is not the most important goal. The main role that alder plays is anti-erosion protection of disposal sites and the species' phytoremediation function connected with their ability to produce large amounts of easily degradable organic matter with high nutrient content resulting in faster rate of soil formation and preparation of habitat for target species such as Scots pine, common birch, maples, and oaks. Earlier study on the introduction of 
grey and black alder on combustion waste disposal sites from bituminous coal and lignite combustion did not bring positive results due to the low survival rate and poor tree growth after 3 years (Wysocki, 1979). However, the site preparation for planting was different than in our study and included various fertilisation combinations, admixture of fertile soil, tertiary acid sands, bentonite, and peat. In order to protect from erosion, the site was sprayed with latex emulsions and a mix of herbaceous plants was sown. Failure of that trial might have resulted also from severe weather conditions (drought and low temperatures) and the impact of industrial pollution in those years, in particular by sulphur compounds and the resulting acid rain (Wysocki, 1979). Our study indicated that the tested alder species were able to survive on the combustion wastes and positively affected their properties. However, in the harsh habitat conditions of combustion waste disposal sites, the process of spontaneous decline of alders, similar to that on reclaimed mining sites, may occur in the future. Observations from afforested postmining sites where alders were introduced as a phytoameliorative admixture indicate their decline within approximately 15-20 years. The process of alder decline is due to both habitat conditions, which are far from the ecological optimum (rainfall-retention water management), as well as from competition with target species of trees whose growth rate accelerates. However, during this period, alders often fulfil an important role in shaping the biotope (Pietrzykowski, 2015). In particular, they increase the pools of nitrogen and soil organic matter (Resh et al., 2002; Binkley, 2005; Krzaklewski et al., 2012).

Table 1. Effects of treatment $(\mathrm{CCW}, \mathrm{CCW}+\mathrm{L}$,$) and tree species on alder growth parameters on$ the combustion waste landfill by two-way ANOVA.

\begin{tabular}{|c|c|c|c|c|c|c|c|}
\hline Effect & $\begin{array}{c}\mathrm{D} \\
\text { trees ha-1 }\end{array}$ & $\begin{array}{c}\text { Survival } \\
\% \\
\end{array}$ & SDI & $\begin{array}{c}\mathrm{DBH} \\
\mathrm{cm}\end{array}$ & $\begin{array}{l}\mathrm{H} \\
\mathrm{m}\end{array}$ & $\begin{array}{c}\Delta \mathrm{H}^{3} \\
\mathrm{~m} \mathrm{yr}^{-1}\end{array}$ & $\begin{array}{c}\mathrm{H} 100 \\
\mathrm{~m}\end{array}$ \\
\hline $\mathrm{Sp}^{*}$ & N.S. \# & N.S. & S. & S. & S. & S. & N.S. \\
\hline B.a. $(n=8)$ & $4423 \pm 714 t$ & $73 \pm 4$ & $507.6 \pm 109.8^{\mathrm{b}}+\dagger$ & $6.4 \pm 0.2^{b}$ & $6.3 \pm 0.2^{\mathrm{b}}$ & $0.65 \pm 0.11^{\mathrm{b}}$ & $9.0 \pm 1.0$ \\
\hline G.a. $(n=8)$ & $4583 \pm 798$ & $72 \pm 5$ & $234.5 \pm 50.9^{\mathrm{a}}$ & $3.9 \pm 0.2^{\mathrm{a}}$ & $3.9 \pm 0.2^{\mathrm{a}}$ & $0.29 \pm 0.11^{\mathrm{a}}$ & $8.5 \pm 1.3$ \\
\hline $\operatorname{Tr} \dagger$ & N.S. & N.S. & S. & N.S. & S. & N.S. & N.S. \\
\hline $\mathrm{CCW}(\mathrm{n}=8)$ & $4407 \pm 699$ & $69 \pm 4$ & $321.3 \pm 157.6^{\mathrm{a}}$ & $4.8 \pm 0.2$ & $4.9 \pm 0.3^{\mathrm{a}}$ & $0.43 \pm 0.20$ & $8.2 \pm 1.0$ \\
\hline $\mathrm{CCW}+\mathrm{L}(\mathrm{n}=8)$ & $4888 \pm 835$ & $76 \pm 5$ & $424.5 \pm 179.01^{\mathrm{b}}$ & $5.4 \pm 0.2$ & $5.6 \pm 0.2^{\mathrm{b}}$ & $0.51 \pm 0.21$ & $9.1 \pm 1.4$ \\
\hline $\mathrm{Sp} \times \operatorname{Tr} \mathbb{I}$ & N.S. & N.S. & N.S. & N.S. & N.S. & N.S. & N.S. \\
\hline \multicolumn{8}{|c|}{ 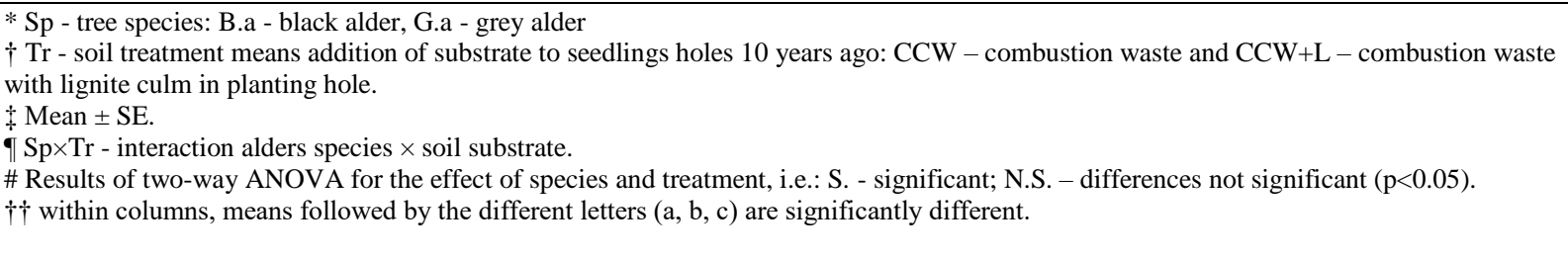 } \\
\hline
\end{tabular}




\section{Uppermost litter horizon properties}

Dry litter mass under all the investigated alder species was similar and ranged from $0.29 \mathrm{~kg} \mathrm{~m}^{2}$ to $0.36 \mathrm{~kg} \mathrm{~m}^{2}$. Soil treatment and its interaction with tree species, did not have significant effect on the investigated uppermost organic horizon properties, however the tree species did. The litter of black and grey alder showed significantly higher acidity than the green alder litter. According to the soil acidity scale by Soil Science Division Staff (2017), the organic horizon $\left(\mathrm{O}_{1}\right)$ under grey and black alder was slightly acidic $\left(\mathrm{pH}_{\mathrm{H} 2 \mathrm{O}}=6.42-6.45, \mathrm{pH}_{\mathrm{KCl}}=6.33-6.43\right)$, whereas under green alder, it was neutral $\left(\mathrm{pH}_{\mathrm{H} 2 \mathrm{O}}=6.73 ; \mathrm{pH}_{\mathrm{KCl}}=6.68\right.$, respectively) compared to the other alder species. The highest $\mathrm{N}$ and $\mathrm{P}$ content in litter was under grey alder $\left(19.90 \mathrm{~g} \mathrm{~kg}^{-1}\right.$ and $0.98 \mathrm{~g} \mathrm{~kg}^{-1}$ respectively). The content of these elements in Oi under green alder was significantly lower (N: $16.16 \mathrm{~g} \mathrm{~kg}^{-1}$ and P: $0.77 \mathrm{~g} \mathrm{~kg}^{-1}$ ). The $\mathrm{N}$ content in the organic horizon under black alder (19.01 $\mathrm{g} \mathrm{kg}^{-1}$ ) was similar to that under grey alder, but $\mathrm{P}$ content was significantly lower $\left(0.72 \mathrm{~g} \mathrm{~kg}^{-1}\right)$. The $\mathrm{C}: \mathrm{N}$ ratio in the organic horizon ranged from 18 under green alder to 20 under grey alder. Potassium content under grey alder $\left(1.35 \mathrm{~g} \mathrm{~kg}^{-1}\right)$ was higher than under black alder $\left(1.06 \mathrm{~g} \mathrm{~kg}^{-1}\right)$ and green alder $\left(0.77 \mathrm{~g} \mathrm{~kg}^{-1}\right)$. On the other hand, Ca content under green alder (46.81 $\left.\mathrm{g} \mathrm{kg}^{-1}\right)$ was higher than under grey alder $\left(31.02 \mathrm{~g} \mathrm{~kg}^{-1}\right)$ and black alder $\left(35.12 \mathrm{~g} \mathrm{~kg}^{-1}\right)$. Magnesium content $\left(2.76 \mathrm{~g} \mathrm{~kg}^{-1}-3.43 \mathrm{~g} \mathrm{~kg}^{-1}\right.$ ) was similar under all alder species (Table 2).

The $\mathrm{O}_{1}$ horizons under grey alder had significantly lower $\mathrm{C}_{\text {mic }}\left(5617 \mu \mathrm{g} \mathrm{g}^{-1}\right)$ and exhibited lower respiration rate $\left(814 \mu \mathrm{g} \mathrm{C}-\mathrm{CO}_{2} \mathrm{~g}^{-1} 24 \mathrm{~h}^{-1}\right)$ than the horizons under black and grey alders $\left(\mathrm{C}_{\text {mic }}: 8984\right.$ - $9446 \mu \mathrm{g} \mathrm{g}{ }^{-1}$; RESP: 252 - 291 $\mu \mathrm{g}$ C-CO $\mathrm{CO}^{-1} 24 \mathrm{~h}^{-1}$ ). However, there was no effect of lignite addition on the $\mathrm{C}_{\text {mic }}$ and RESP values in Oi horizons and no significant interaction between plant species and treatment (Table 2). 
Table 2. Properties of organic horizon $\left(\mathrm{O}_{1}\right)$ developing after 10 years under the alder stands on a combustion waste disposal site.

\begin{tabular}{|c|c|c|c|c|c|c|c|c|c|c|c|c|}
\hline Effect & $\begin{array}{c}\text { Mass (dry) } \\
\mathrm{kg} \mathrm{m}^{2}\end{array}$ & $\mathrm{pH}_{\mathrm{H} 2 \mathrm{O}}$ & $\mathrm{pH}_{\mathrm{KCl}}$ & $\begin{array}{c}\mathrm{N} \\
\mathrm{g} \mathrm{kg}^{-1}\end{array}$ & $\mathrm{C}: \mathrm{N}$ & $\begin{array}{c}P \\
-\ldots-\ldots\end{array}$ & $\mathrm{K}$ & $\mathrm{Ca}$ & $\mathrm{Mg}$ & $\mathrm{Na}$ & $\begin{array}{c}\mathrm{C}_{\text {mic }} \\
\mu \mathrm{g} \mathrm{g}^{-1}\end{array}$ & $\begin{array}{c}\text { RESP } \\
\mu \mathrm{g} \mathrm{C}-\mathrm{CO}_{2} \mathrm{~g}^{-1} \\
24 \mathrm{~h}^{-1} \\
\end{array}$ \\
\hline $\mathrm{Sp}^{*}$ & N.S." & $\mathrm{S}$. & S. & $\mathrm{S}$. & S. & S. & S. & S. & N.S. & S. & S. & S. \\
\hline $\begin{array}{l}\text { B.a } \\
(n=8)\end{array}$ & $0.36 \pm 0.03 \ddagger$ & $6.42 \pm 0.08^{\mathrm{a}} \uparrow \dagger$ & $6.33 \pm 0.13^{\mathrm{a}}$ & $19.01 \pm 0.69^{\mathrm{ab}}$ & $19 \pm 1^{\mathrm{ab}}$ & $0.72 \pm 0.02^{\mathrm{a}}$ & $1.06 \pm 0.07^{\mathrm{b}}$ & $35.12 \pm 2.91^{\mathrm{a}}$ & $3.34 \pm 0.19$ & $0.21 \pm 0.04^{\mathrm{a}}$ & $8984 \pm 2381^{\mathrm{a}}$ & $1828 \pm 408^{a}$ \\
\hline $\begin{array}{l}\text { G.a } \\
(n=8)\end{array}$ & $0.29 \pm 0.04$ & $6.45 \pm 0.06^{\mathrm{a}}$ & $6.43 \pm 0.09^{\mathrm{a}}$ & $19.90 \pm 0.99^{b}$ & $20 \pm 1^{b}$ & $0.98 \pm 0.03^{b}$ & $1.35 \pm 0.08^{\mathrm{c}}$ & $31.02 \pm 2.29^{\mathrm{a}}$ & $2.76 \pm 0.19$ & $0.18 \pm 0.03^{\mathrm{a}}$ & $9446 \pm 2995^{\mathrm{a}}$ & $1485 \pm 478^{\mathrm{a}}$ \\
\hline $\begin{array}{l}\text { Gr.a } \\
(n=8)\end{array}$ & $0.29 \pm 0.06$ & $6.73 \pm 0.10^{\mathrm{b}}$ & $6.68 \pm 0.10^{\mathrm{b}}$ & $16.16 \pm 0.88^{a}$ & $18 \pm 1^{\mathrm{a}}$ & $0.77 \pm 0.03^{\mathrm{a}}$ & $0.77 \pm 0.09^{\mathrm{a}}$ & $46.81 \pm 2.11^{\mathrm{b}}$ & $3.43 \pm 0.23$ & $0.34 \pm 0.04^{b}$ & $5617 \pm 2250^{\mathrm{b}}$ & $814 \pm 360^{b}$ \\
\hline $\operatorname{Tr} \dagger$ & N.S. & N.S. & N.S. & N.S. & N.S. & N.S. & N.S. & N.S. & N.S. & N.S. & N.S. & N.S. \\
\hline $\begin{array}{l}\mathrm{CCW} \\
(\mathrm{n}=12)\end{array}$ & $0.27 \pm 0.03$ & $6.54 \pm 0.07$ & $6.49 \pm 0.08$ & $18.32 \pm 0.68$ & $19 \pm 1$ & $0.81 \pm 0.04$ & $1.09 \pm 0.07$ & $37.64 \pm 2.09$ & $3.15 \pm 0.16$ & $0.24 \pm 0.03$ & $7734 \pm 3146$ & $1364 \pm 620$ \\
\hline $\begin{array}{l}\mathrm{CCW}+\mathrm{L} \\
(\mathrm{n}=12)\end{array}$ & $0.36 \pm 0.04$ & $6.52 \pm 0.09$ & $6.47 \pm 0.11$ & $18.39 \pm 0.98$ & $19 \pm 1$ & $0.84 \pm 0.04$ & $1.04 \pm 0.11$ & $37.66 \pm 3.39$ & $3.20 \pm 0.21$ & $0.25 \pm 0.04$ & $8294 \pm 2969$ & $1387 \pm 579$ \\
\hline $\begin{array}{l}\mathrm{Sp} \times \operatorname{Tr}^{\mathrm{fl}} \\
(\mathrm{n}=24)\end{array}$ & N.S. & N.S. & N.S. & N.S. & N.S. & N.S. & N.S. & N.S. & N.S. & N.S. & N.S. & N.S. \\
\hline
\end{tabular}

* Sp - tree species: B.a - black alder, G.a - grey alder, Gr.a - green alder.

$\dagger \mathrm{Tr}$ - soil treatment means addition of substrate to seedlings holes 10 years ago: $\mathrm{CCW}$ - combustion waste and CCW $+\mathrm{L}-$ combustion waste with lignite culm in planting hole. \pm Mean \pm SE.

II $\mathrm{Sp} \times \mathrm{Tr}$ - interaction alders species $\times$ soil substrate

\# Results of two-way ANOVA for the effect of species and treatment, i.e.: S. - significant; N.S. - differences not significant ( $<<0.05$ ).

$\dagger+$ Within columns, means followed by the different letters (a, b, c) are significantly different.

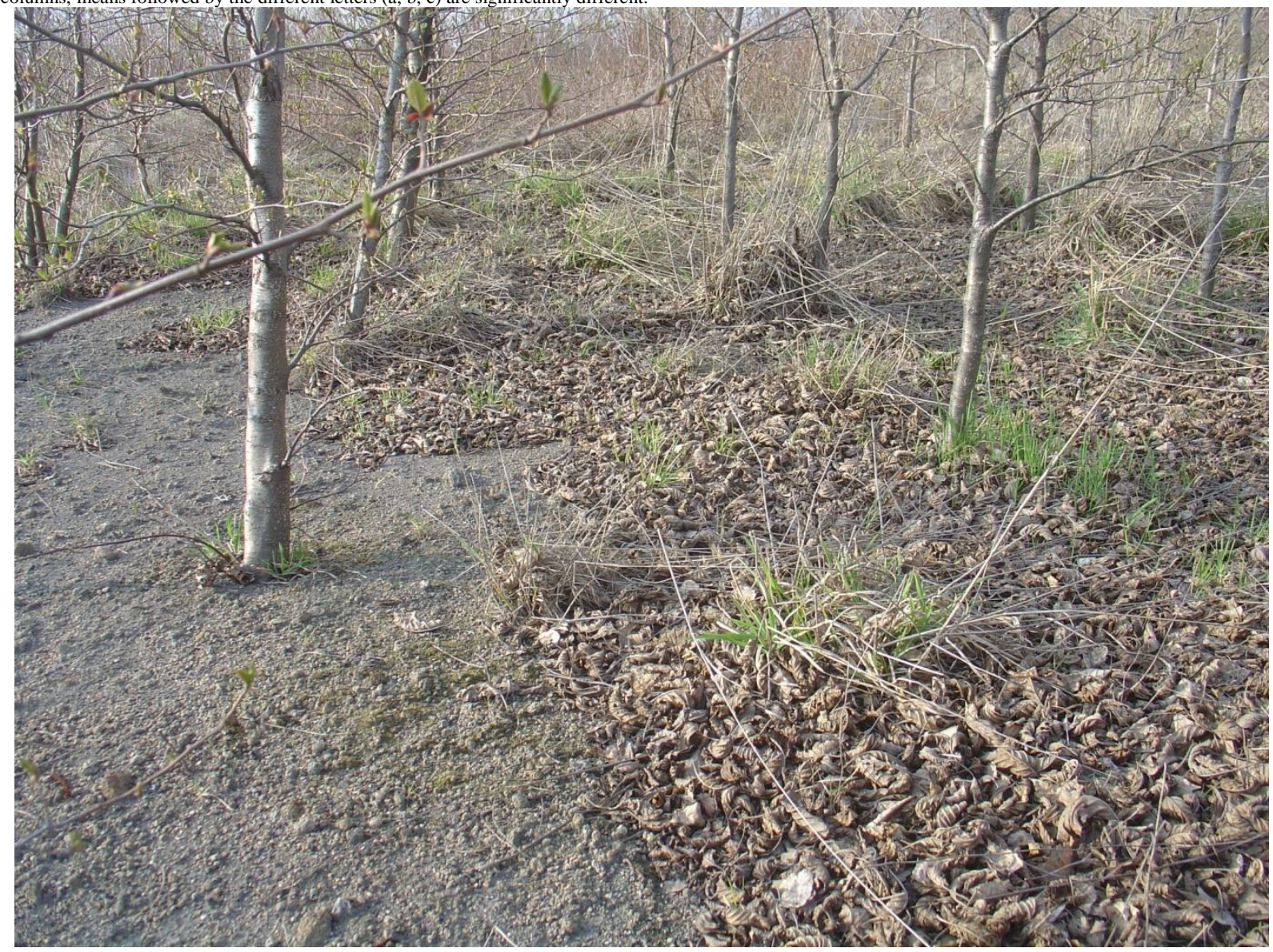

Figure 8. Accumulation of fresh litter under alders' canopy growing on combustion waste disposal site (spring 2010). Photo by M. Pietrzykowski. 


\section{$\underline{\text { Technosol basic characteristics }}$}

The initial sample of freshly collected combustion waste displayed low content of silt and clay (ca. $1 \%$ for both), was alkaline $\left(\mathrm{pH}_{\mathrm{H} 2 \mathrm{O}}=8.52, \mathrm{pH}_{\mathrm{KCl}}=8.60\right)$, and had high salt content as indicated by high EC (1586.67 $\left.\mu \mathrm{S} \mathrm{cm}^{-1}\right)$. Exchangeable acidity (Hh) in the sample of freshly collected combustion waste was low $\left(0.74 \mathrm{cmol}(+) \mathrm{kg}^{-1}\right), \mathrm{CEC}$ was $17.53 \mathrm{cmol}(+) \mathrm{kg}^{-1}$, and $\mathrm{BS} 95.77 \%$ (Table 3).

Alder species, soil treatment, and their interaction had no significant effect on the texture, $\mathrm{pH}_{\mathrm{H} 2 \mathrm{O}}, \mathrm{pH}_{\mathrm{KCl}}, \mathrm{EC}, \mathrm{Hh}$, and CEC of the studied technosols (Table 3). However, basic properties of technosols under alders differed distinctly from the properties of freshly collected combustion waste. The contents of silt ranged from $14 \%$ to $19 \%$, clay from $1 \%$ to $2 \%$, and of $\mathrm{CaCO}_{3}$ from 3.53 to $4.81 \%$. The investigated soils were slightly alkaline $\left(\mathrm{pH}_{\mathrm{H} 2 \mathrm{O}} 7.74-7.80, \mathrm{pH}_{\mathrm{KCl}} 7.40-7.42\right)$, EC was 157.38 to $193.00 \mu \mathrm{S} \mathrm{cm}^{-1}$. Their exchangeable acidity (Hh) remained low and ranged from 0.86 to $0.93 \mathrm{cmol}(+) \mathrm{kg}^{-1}$. The CEC ranged from 28.85 to $32.19 \mathrm{cmol}^{(+)} \mathrm{kg}^{-1}$, and BS from 96.89 to $97.14 \%$. The $\mathrm{C}_{\text {mic }}$ and RESP values in the mineral soil were much lower than in the Oi horizon and ranged from $241-291 \mu \mathrm{g} \mathrm{g} \mathrm{g}^{-1}$ and from $35-40 \mu \mathrm{g}$ C-CO $\mathrm{g}^{-1} 24 \mathrm{~h}^{-1}$, respectively. Neither $\mathrm{C}_{\text {mic }}$ nor RESP were affected by the alder species, soil treatment or interaction of these two factors (Table 3). Changes of some of the properties (e.g., texture or EC) were not related to the presence of alders but resulted probably from natural processes such as weathering or leaching. However, alders might have participated to the changes in $\mathrm{pH}, \mathrm{CEC}$, or $\mathrm{CaCO}_{3}$.

Tree species may lower $\mathrm{pH}$ of the top soil horizons due to organic acids leaching form the litterfall (Finzi et al., 1998). In the case of alders, this process may be enhanced by atmospheric nitrogen binding, followed by intensive microbial oxidation of $\mathrm{N}$-rich litter producing $\mathrm{HNO}_{3}$, which significantly accelerates soil acidification (Van Miegroet and Cole, 1984). This pronounced acidification effect of alders was found both in natural habitats (e.g., Van Miegroet and Cole, 1984; Cole et al., 1990) and in reclaimed post-mining soils (e.g., Chodak and Niklińska, 2010). In the case of fly ash disposal sites, the decrease in $\mathrm{pH}$ from strongly alkaline to less alkaline or acidic is favourable and is one of the main indicators of soil formation processes (Uzarowicz et al., 2017), and one of the conditions for the success of revegetation (Krzaklewski et al., 2012). The observed decrease in $\mathrm{pH}$ (measured in $\mathrm{KCl}$ ) in the top horizons of technosols by more than 1.0 unit compared to the freshly deposited waste and the increase of hydrolytic acidity (Hh) emphasise the beneficial phytoamelioration effect of the alder already after 10 years of growth. 
The CEC of technosols increased under alders compared with the freshly collected combustion waste probably due to accumulation of SOC (Table 3). An increase in soil SOC raises the cation exchange capacity (Kaiser and Ellerbrock, 2005). It is estimated that as a result of a 1\% SOC increase in the soil, the sorption capacity increases by about $3 \mathrm{cmol}(+) \mathrm{kg}^{-1}$ (McBride, 1994). In line with our results, Cole et al. (1990) found a beneficial effect of alder on the soil sorption capacity improvement.

Table 3. Basic properties of technosol $0-5 \mathrm{~cm}$ horizon after 10 years under the alder stands in a combustion waste disposal site.

\begin{tabular}{|c|c|c|c|c|c|c|c|c|c|c|c|c|}
\hline \multirow{2}{*}{ Effect } & Silt & Clay & $\mathrm{CaCO}_{3}$ & \multirow{2}{*}{$\mathrm{pH}_{\mathrm{H} 2 \mathrm{O}}$} & \multirow{2}{*}{$\mathrm{pH}_{\mathrm{KCl}}$} & \multirow{2}{*}{$\begin{array}{c}\mathrm{EC} \\
\mu \mathrm{S} \mathrm{cm}^{-1}\end{array}$} & \multirow[t]{2}{*}{$\mathrm{Hh}$} & \multirow{2}{*}{ TEB } & \multirow{2}{*}{ CEC } & \multirow{2}{*}{$\begin{array}{l}\text { BS } \\
\%\end{array}$} & \multirow{2}{*}{$\begin{array}{l}\mathrm{C}_{\mathrm{mic}} \\
\mu \mathrm{g} \mathrm{g}^{-1} \\
\end{array}$} & \multirow{2}{*}{$\begin{array}{c}\text { RESP } \\
\mu \mathrm{g} \mathrm{C} \_\mathrm{CO}_{2} \mathrm{~g}^{-1} 24 \mathrm{~h}^{-1}\end{array}$} \\
\hline & $\ldots$ & $-\%---$ & - - - - - & & & & & & & & & \\
\hline $\begin{array}{l}\text { Control } \\
\text { sample }\end{array}$ & $1 \pm 0$ & $1 \pm 0$ & $5.44 \pm 0.17$ & $8.52 \pm 0.08$ & $8.60 \pm 0.10$ & $1586.67 \pm 56.96$ & 0.74 & 16.79 & 17.53 & 95.77 & - & - \\
\hline $\mathrm{Sp}^{*}$ & N.S.\# & N.S. & N.S. & N.S. & N.S. & N.S. & N.S. & N.S. & N.S. & N.S. & N.S. & N.S. \\
\hline B.a. & $14 \pm 4 \dagger$ & $1 \pm 0$ & $3.66 \pm 0.79$ & $7.74 \pm 0.02$ & $7.40 \pm 0.02$ & $193.00 \pm 16.59$ & $0.93 \pm 0.04$ & $29.85 \pm 1.76$ & $30.78 \pm 1.79$ & $96.94 \pm 0.09$ & $291 \pm 91$ & $39 \pm 12$ \\
\hline G.a. & $19 \pm 4$ & $1 \pm 0$ & $4.19 \pm 0.94$ & $7.80 \pm 0.03$ & $7.42 \pm 0.03$ & $186.13 \pm 13.87$ & $0.86 \pm 0.04$ & $29.11 \pm 1.04$ & $29.97 \pm 1.05$ & $97.12 \pm 0.12$ & $252 \pm 48$ & $36 \pm 8$ \\
\hline Gr.a. & $19 \pm 6$ & $2 \pm 0$ & $4.66 \pm 1.61$ & $7.79 \pm 0.03$ & $7.41 \pm 0.02$ & $157.38 \pm 8.04$ & $0.91 \pm 0.06$ & $29.90 \pm 1.81$ & $30.82 \pm 1.81$ & $96.99 \pm 0.23$ & $241 \pm 77$ & $37 \pm 12$ \\
\hline $\operatorname{Tr} \dagger$ & N.S. & N.S. & N.S. & N.S. & N.S. & N.S. & N.S. & N.S. & N.S. & N.S. & N.S. & N.S. \\
\hline $\mathrm{CCW}$ & $19 \pm 4$ & $1 \pm 0$ & $4.81 \pm 1.11$ & $7.77 \pm 0.02$ & $7.41 \pm 0.02$ & $180.33 \pm 12.60$ & $0.91 \pm 0.04$ & $31.28 \pm 1.33$ & $32.19 \pm 1.34$ & $97.14 \pm 0.11$ & $270 \pm 86$ & $40 \pm 12$ \\
\hline $\mathrm{CCW}+\mathrm{L}$ & $16 \pm 3$ & $1 \pm 0$ & $3.53 \pm 0.68$ & $7.78 \pm 0.02$ & $7.41 \pm 0.01$ & $177.33 \pm 10.48$ & $0.89 \pm 0.04$ & $28.00 \pm 0.97$ & $28.85 \pm 0.98$ & $96.89 \pm 0.14$ & $252 \pm 64$ & $35 \pm 8$ \\
\hline $\operatorname{Sp} \times \operatorname{Tr}^{\pi}$ & N.S. & N.S. & N.S. & N.S. & N.S. & N.S. & N.S. & N.S. & N.S. & N.S. & N.S. & N.S. \\
\hline
\end{tabular}

$\underline{\text { Soil organic carbon and nitrogen content in combustion waste technosols }}$

Freshly deposited combustion waste contained $19.46 \mathrm{~g} \mathrm{~kg}^{-1}$ of $\mathrm{C}$ being a residue of lignite unburnt in the power plant (Klotz et al., 2004; Uzarowicz et al., 2017). All the introduced alder species significantly affected SOC content in the mineral horizon of technosol compared with the samples of freshly deposited combustion waste. The SOC content in technosols (after subtracting unburnt lignite in the balance sheet) after 10 years of alder growth increased to $18.60 \mathrm{~g} \mathrm{~kg}^{-1}$ $28.34 \mathrm{~g} \mathrm{~kg}^{-1}$ under alders, wherein the effects of species, lignite addition, and their interaction were not significant (Table 4). The measured SOC values may be considered high compared to data from other post-industrial sites. For instance, on the dumps of the former sulphur opencast mine (southern Poland) where alder was introduced 25-35 years ago, the SOC contents depended on the substrate texture and were from $14.1 \mathrm{~g} \mathrm{~kg}^{-1}$ on quaternary loams to $60.4 \mathrm{~g} \mathrm{~kg}^{-1}$ on Neogene clays (Józefowska et al., 2016). It should be emphasised that high SOC content in Neogene clays 
resulted from the presence of geologic organic matter in the form of bituminous sea accumulation (Pawłowski et al., 1985). Alders as the $\mathrm{N}$-fixing species may support intensive accumulation of SOC (Resh et al., 2002; Binkley, 2005). Higher SOC content in soils under tree species capable of symbiosis with atmospheric nitrogen-fixing bacteria compared to soils under other tree species was reported from both natural temperate soils (Binkley, 2005) and the tropical climate zone (Resh et al. 2002). This increased organic carbon content in the soil under species capable of assimilating atmospheric nitrogen is associated with biological changes due to the nitrogen-rich litter fall (Binkley, 2005). High $\mathrm{N}$ contents in the litter favour rapid initial decomposition but inhibit decomposition of humified soil C (Berg, 2000).

Similar accumulation of SOC under all tested alder species resulted in similar microbial biomass and respiration activity of the studied technosols (Table 3). Indeed, organic $\mathrm{C}$ has been described as the most important control on soil microbial biomass and its activity in natural and reclaimed soils (Kaiser et al., 1992; Chodak and Niklińska, 2010).

Freshly deposited combustion waste had low $\mathrm{N}_{\text {tot }}$ content of $0.25 \mathrm{~g} \mathrm{~kg}^{-1}$ originating from the unburnt lignite (Klotz et al., 2004; Uzarowicz et al. 2017). All the introduced alder species distinctly affected the accumulation of $\mathrm{N}_{\text {tot }}$ in the mineral horizon of technosols in relation to the samples of freshly deposited combustion waste. The $\mathrm{N}_{\text {tot }}$ content in the technosols (after subtracting nitrogen content of unburnt lignite in the initial balance) after 10 years of growth was $0.87 \mathrm{~g} \mathrm{~kg}^{-1}$ under green alder, $1.16 \mathrm{~g} \mathrm{~kg}^{-1}$ under grey alder, and $1.57 \mathrm{~g} \mathrm{~kg}^{-1}$ under black alder, and the difference between green alder and black alder was statistically significant. Lignite addition into the planting holes did not affect the $\mathrm{N}$ accumulation (Table 4). Nitrogen is the most deficient nutrient in the young technosols, therefore its dynamic accumulation of nitrogen is one of the basic phytoamelioration outcomes of alders. The development of symbiotic nitrogen-fixing microflora may, however, be hampered by the unfavourable properties of combustion waste (Cheung et al., 2000). In a greenhouse study, it was demonstrated that the application of symbiotic bacteria of Rhizobium species for legume species Acacia auriculiformis and Leucaena leucocephala introduced on the combustion waste failed, even after the addition of various enhancing substrates, including 30\% vermiculite and compost (Cheung et al., 2000). We did not perform detailed biological tests to identify Actinobacteria communities which participated in nitrogen assimilation and we could not determine whether there were factors limiting this process. Nevertheless, the impact of alders was evident and manifested in increased contents of $\mathrm{N}$ in the uppermost soil 
horizons. Józefowska et al. (2016) reported the $\mathrm{N}$ content in soils on a forested dump of a former sulphur opencast mine ranging from $1.2 \mathrm{~g} \mathrm{~kg}^{-1}$ on quaternary loams to $5.4 \mathrm{~g} \mathrm{~kg}^{-1}$ on Neogene clays. However, the highest $\mathrm{N}$ contents in their materials were related to the presence of marine bituminous deposits (Pawłowski et al., 1985). Our data obtained after 10 years of alders' growth indicated that the $\mathrm{N}$ accumulation in the combustion waste under alders was high and confirmed beneficial phytoameliorative effect, especially of woody alder species (grey and black alder).

Table 4. Organic carbon (SOC), total nitrogen $\left(\mathrm{N}_{\mathrm{t}}\right)$ content, and $\mathrm{C}: \mathrm{N}$ ratio in the $0-5 \mathrm{~cm}$ technosol horizon after 10 years under the alder stands on a combustion waste disposal site. The SOC and $\mathrm{N}_{\mathrm{t}}$ contents in soils under alders (B.a, G.a., Gr.a., CCW, and CCW+L) are given after subtracting the SOC and Nt contents in the control sample.

\begin{tabular}{|c|c|c|c|}
\hline \multirow[t]{2}{*}{ Effect } & $\mathrm{SOC}$ & $\mathrm{N}_{\mathrm{t}}$ & \multirow[t]{2}{*}{$\mathrm{C}: \mathrm{N}$} \\
\hline & \multicolumn{2}{|c|}{ - n kg } & \\
\hline Control sample & $19.46 \pm 0.13$ & $0.25 \pm 0.01$ & - \\
\hline $\mathrm{Sp}^{*}$ & N.S. ${ }^{\#}$ & S. & N.S. \\
\hline B.a. & $28.34 \pm 13.50 \ddagger$ & $1.57 \pm 0.67^{\mathrm{b}}+\dagger$ & $19 \pm 5$ \\
\hline G.a. & $21.93 \pm 10.09$ & $1.16 \pm 0.24^{\mathrm{ab}}$ & $18 \pm 6$ \\
\hline Gr.a. & $18.60 \pm 11.68$ & $0.87 \pm 0.36^{\mathrm{a}}$ & $20 \pm 7$ \\
\hline $\operatorname{Tr} \dagger$ & N.S. & N.S. & N.S. \\
\hline $\mathrm{CCW}$ & $23.72 \pm 5.02$ & $1.26 \pm 0.56$ & $18 \pm 9$ \\
\hline $\mathrm{CCW}+\mathrm{L}$ & $22.19 \pm 9.79$ & $1.14 \pm 0.40$ & $20 \pm 13$ \\
\hline $\operatorname{Sp} \times \operatorname{Tr}^{\mathbb{I}}$ & N.S. & N.S. & N.S. \\
\hline \multicolumn{4}{|c|}{$\begin{array}{l}\text { * Sp - tree species: B.a - black alder, G.a - grey alder, Gr.a - green alder. } \\
\dagger \mathrm{Tr} \text { - soil treatment means addition of substrate to seedlings holes } 10 \text { years ago: } \\
\mathrm{CCW}-\text { combustion waste and } \mathrm{CCW}+\mathrm{L}-\text { combustion waste with lignite culm in } \\
\text { planting hole. } \\
+ \text { mean } \pm \text { SE. } \\
\text { II Sp } \times \text { Tr - interaction alders species } \times \text { soil substrate. } \\
\text { \# results of two-way ANOVA for the effect of species and treatment, i.e.: S. } \\
\text { significant; N.S. - differences not significant }(\mathrm{p}=0.05) \text {. } \\
\dagger \dagger \text { within columns, means followed by the different letters }(\mathrm{a}, \mathrm{b}, \mathrm{c}) \text { are significantly } \\
\text { different. }\end{array}$} \\
\hline
\end{tabular}

\section{Macro-element content in combustion waste technosols}

In the uppermost soil horizon, no differences in available phosphorus were found between the tree species. Likewise, there was no increase in available phosphorus content after 10 years of alder growth as compared to the values in the initial samples. On the contrary, the measured $\mathrm{P}_{\mathrm{av}}$ contents $\left(0.01 \mathrm{~g} \mathrm{~kg}^{-1}-0.02 \mathrm{~g} \mathrm{~kg}^{-1}\right)$ were lower than in the freshly deposited combustion waste $\left(0.05 \mathrm{~g} \mathrm{~kg}^{-1}\right)$ (Table 5). Phosphorus, next to nitrogen, is the most deficient element in combustion waste (Haynes, 2009). For this reason, phosphorus may be intensively incorporated into the 
biological cycle and accumulated in the biomass and the organic horizon (litter) (Harrison et al., 1996). However, reports on the effect of $\mathrm{N}$-fixing species on the $\mathrm{P}_{\mathrm{av}}$ content in soils are ambiguous. For instance, red alder introduced as an admixture in Douglas fir stands, increased the amount of available phosphorus in the soil compared to pure Douglas fir stands (Giardina et al., 1995). However, in homogenous stands, red alder caused a significant decrease in phosphorus availability in the soil compared to Douglas fir stands (Harrison et al., 1996). In a chrono-sequence of alder stands aged from 15 to 76 years old growing on the former lignite mine sites in the Czech Republic, there was no significant change in the content of available phosphorus, but it tended to decrease in older age classes (Bartuska and Frouz, 2015). Decreases might also have been due to the presence of large amounts of $\mathrm{Ca}^{2+}$ cations released upon $\mathrm{CaCO}_{3}$ weathering. At high $\mathrm{pH}$, phosphate ions react rapidly with $\mathrm{Ca}$ ions to form insoluble compounds thus decreasing $\mathrm{P}_{\mathrm{av}}$ contents (Hinsinger, 2001).

Differences in the contents of exchangeable cations between particular alder species were negligible - only $\mathrm{Mg}^{2+}$ content was significantly higher under black alder than for green alder. However, alders affected the contents of exchangeable cations as compared with the freshly deposited combustion waste. In particular the contents of exchangeable $\mathrm{Ca}^{2+}$ and $\mathrm{K}^{+}$were increased under alders (Table 5). We presume that the higher contents of these cations resulted from increased cation exchange capacity of technosols. Owing to organic matter accumulation the CEC of technosols was nearly twice as large as the CEC of freshly deposited combustion waste. In consequence, the cations released during weathering processes could have been absorbed in larger amounts. 
Table 5. Nutrient content $\left(\mathrm{P}_{\mathrm{av}}, \mathrm{Ca}^{2+}, \mathrm{Mg}^{2+}, \mathrm{K}^{+}, \mathrm{Na}^{+}\right)$in the $0-5 \mathrm{~cm}$ technosol horizon after 10 years under the alder stands on a combustion waste disposal site.

\begin{tabular}{|c|c|c|c|c|c|}
\hline Level & $\mathrm{P}_{\mathrm{av}}$ & $\mathrm{Ca}^{2+}$ & $\begin{array}{c}\mathrm{Mg}^{2+} \\
\ldots-\mathrm{g} \mathrm{kg}^{-1} \ldots\end{array}$ & $\mathrm{K}^{+}$ & $\mathrm{Na}^{+}$ \\
\hline $\begin{array}{l}\text { Control } \\
\text { sample }\end{array}$ & 0.05 & 3.25 & 0.13 & 0.05 & 0.01 \\
\hline $\mathrm{Sp}^{*}$ & N.S. ${ }^{\#}$ & N.S. & S. & N.S. & N.S. \\
\hline B.a. & $0.02 \pm 0.00 \ddagger$ & $5.54 \pm 0.32$ & $0.20 \pm 0.02^{\mathrm{b}} \dagger \dagger$ & $0.19 \pm 0.02$ & $0.01 \pm 0.00$ \\
\hline G.a. & $0.01 \pm 0.00$ & $5.44 \pm 0.20$ & $0.16 \pm 0.01^{\mathrm{ab}}$ & $0.24 \pm 0.03$ & $0.01 \pm 0.00$ \\
\hline Gr.a. & $0.02 \pm 0.01$ & $5.71 \pm 0.35$ & $0.12 \pm 0.01^{\mathrm{a}}$ & $0.15 \pm 0.01$ & $0.01 \pm 0.00$ \\
\hline $\operatorname{Tr} \dagger$ & N.S. & S. & N.S. & N.S. & N.S. \\
\hline $\mathrm{CCW}$ & $0.02 \pm 0.00$ & $5.88 \pm 0.25^{\mathrm{b}}$ & $0.17 \pm 0.02$ & $0.20 \pm 0.02$ & $0.01 \pm 0.00$ \\
\hline $\mathrm{CCW}+\mathrm{L}$ & $0.02 \pm 0.00$ & $5.24 \pm 0.18^{\mathrm{a}}$ & $0.15 \pm 0.01$ & $0.19 \pm 0.02$ & $0.01 \pm 0.00$ \\
\hline $\mathrm{Sp} \times \operatorname{Tr}^{\mathrm{Il}}$ & N.S. & N.S. & S. & N.S. & N.S. \\
\hline \multicolumn{6}{|c|}{ 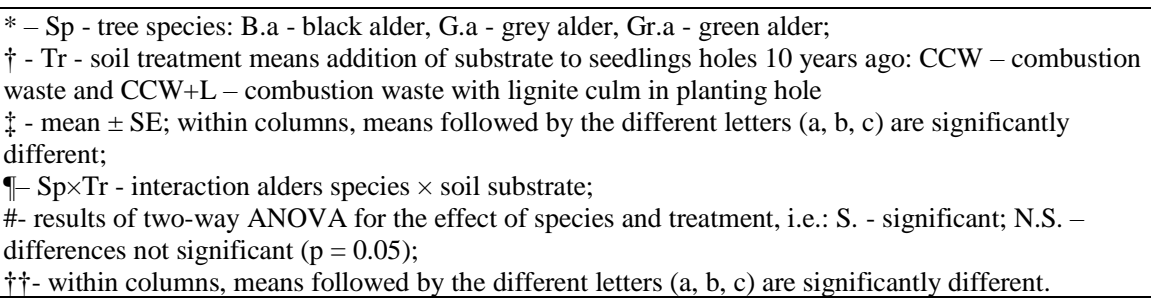 } \\
\hline
\end{tabular}

\section{Conclusions}

The study confirmed usefulness of black and grey alder as bio-stabilisers with good growth parameters. After 10 years, black alder displayed better growth parameters than grey alder, probably due to different ecological characteristics and growth rate at young age. The lignite amendment resulted in higher density index (SDI) and tree height $(\mathrm{H})$. Therefore, initial NPK mineral fertilisation and stabilisation with hydro-seeding with sewage sludge along with admixture of lignite as a substrate into planting holes are recommended to improve growth of alders on reclaimed combustion wastes.

The basic effect of alders on the technosols development on combustion waste after 10 years of stand growth was the accumulation of litter with a narrow $\mathrm{C}: \mathrm{N}$ ratio $(18-20)$ and increase in $\mathrm{N}$ content in the top mineral horizon. This increase occurred under all the investigated alder species, however, the highest concentrations of $\mathrm{N}$ were found under black alder. The three studied alder species similarly stimulated development of microbial biomass and its activity in 
the technosols although in the $\mathrm{O}_{1}$ horizon lower microbial respiration and biomass were found under green alder.

Apart from nitrogen accumulation, a function of forest stands is an important aspect in the selection of alder species for the reclamation of combustion fly-ash disposal sites. If the objectives include not only the phytoameliorative function but also the growth, black alder is strongly recommended. This species exhibits similar effect on the properties of the combustion wastes as grey alder but displays better survival and growth parameters. This in turn, in the long run, ensures greater biomass production and accumulation of organic litter fall which transforms the technogenic soil to the greatest extent. Green alder being a shrub species with lower biomass and litter fall has a slightly weaker phytoamelioration effect when applied to the protection of slopes for erosion.

\section{$\underline{\text { Acknowledgements }}$}

The study was financed by The National Science Centre, Poland, grant No. 2015/17/B/ST10/02712. We would like to express our gratitude to Dawid Leńczuk, PhD student for his photos, and Iwona Skowrońska MSc. for laboratory tests and her kind collaboration. Special thanks to PGE GiEK SA Elektrownia Bełchatów power plant for field work support and access to experimental area of Lubień combustion waste disposal site.

\section{Literature Cited}

Adriano, D.C, A.L. Page, A.A. Elseewi, A.C. Chang, and I. Straughan. 1980. Utilization and disposal of fly ash and other coal residues in terrestrial ecosystems: a review. Journal of Environmental Quality 9: 333-344. https://doi.org/10.2134/jeq1980.00472425000900030001x

Bartuska, M. and J. Frouz. 2015. Carbon accumulation and changes in soil chemistry in reclaimed open-cast coal mining heaps near Sokolov using repeated measurement of chronosequence sites. European Journal of Soil Science 66(1): 104-111. https://doi.org/10.1111/ejss.12185

Berg, B. 2000. Litter decomposition and organic matter turnover in northern forest soils. Forest Ecology and Management 133(1-2): 13-22. https://doi.org/10.1016/S0378-1127(99)00294-7

Binkley, D. 1986. Forest Nutrition Management. John Wiley \& Sons, Inc.

Binkley, D. 2005. How nitrogen-fixing trees change soil carbon. p. 155-164.In: D. Binkley, and O. Menyailo (ed.). Kluwer Academic Publishers, Dordrecht, the Netherlands. 
Boratyński A. 1980. Systematics and geographic distribution of alders. p. 35-71. In: S. Białobok (ed.), Polish Academy of Sciences, Institute of Dendrology, Warszawa - Poznań (in Polish, English summary).

Carlson, C.L., and D.C. Adriano. 1991. Growth and elemental content of two tree species growing on abandoned coal fly ash basins. Journal of Environmental Quality 20:581-587. https://doi.org/10.2134/jeq1991.00472425002000030013x

Čermák, P. 2008. Forest reclamation of dumpsites of coal combustion by-products (CCB). Journal of Forest Science 54: 273-280. https://doi.org/10.17221/6/2008-JFS

Cheung, K.C., J.P.K Wong, Z.Q. Zhang, J.W.C.Wong, and M.H. Wong. 2010. Revegetation of lagoon ash using the legume species Acacia auriculiformis and Leucaena leucocephala. Environmental Pollution 109(1): 75-82. https://doi.org/10.1016/S0269-7491(99)00235-3

Chodak, M. and M. Niklińska. 2010. Effect of texture and tree species on microbial properties of mine soils. Applied Soil Ecology 46: 268-275. https://doi.org/10.1016/j.apsoil.2010.08.002

Cole, D.W., J. Compton, H. Van Miegroet, and P. Homann. 1990. Changes in soil properties and site productivity caused by red alder. Water, Air and Soil Pollution 54: 231-246. https://doi.org/10.1007/BF02385243

Dellantonio, A., W.J. Fitz, F. Repmann, and WW. Wenzel. 2009. Disposal of coal combustion residues in terrestrial systems: contamination and risk management. Journal of Environmental Quality 39:761-775. https://doi.org/10.2134/jeq2009.0068

Finzi, A.C., C.D. Canham, and N. Van Breemen. 1998. Canopy tree-soil interactions within temperate forests: species effects on ph and cations. Ecological Applications 8:447-454 https://doi.org/10.1890/1051-0761(1998)008[0447:CTSIWT]2.0.CO;2

Frouz, J., B. Keplin, V. Pižl, K. Tajovský, J. Starý, A. Lukešová, A. Nováková, V. Balík, L. Háněl, J. Materna, C. Düker, J. Chalupský, J. Rusek,and T. Heinkele.2001. Soil biota and upper soil layer development in two contrasting post-mining chronosequences. Ecological Engineering 17: 275-284. https://doi.org/10.1016/S0925-8574(00)00144-0

Giardina, C.P., S. Huffman, D. Binkley, and B.A. Caldwell. 1995. Alders increase soil phosphorus availability in a Douglas-fir plantation. Canadian Journal of Forest Research 25(10): 16521657. https://doi.org/10.1139/x95-179 
Harrison, R.B., S.P. Gessel, D. Zabowski, C.L. Henry, D. Xue, DW. Cole, and J.E. Compton. 1996. Mechanisms of negative impacts of three forest treatments on nutrient availability. Soil Science Society of America Journal 60 (6): 1622-1628. https://doi.org/10.2136/sssaj1996.03615995006000060005x

Haynes, R.J. 2009. Reclamation and revegetation of fly ash disposal sites - challenges and research needs. Journal of Environmental Management 90: 43-53. https://doi.org/10.1016/j.jenvman.2008.07.003

Hinsinger, P. 2001. Bioavailability of soil inorganic P in the rhizosphere as affected by rootinduced chemical changes: a review. Plant and Soil 237: 173-195. https://doi.org/10.1023/A:1013351617532

Hodgson, D.R. and W.N. Townsend. 1973. The amelioration and revegetation of pulverized fuel ash. p. 247-270.In: M.J. Chadwick and G.T. Goodman (ed.), Gordon and Breach, London.

Józefowska, A., B. Woś, and M. Pietrzykowski. 2016. Tree species and soil substrate effects on soil biota during early soil forming stages at afforested mine sites. Applied Soil Ecology 102: 70-79. https://doi.org/10.1016/j.apsoil.2016.02.012

Kaiser, M. and R.H. Ellerbrock. 2005. Functional characterization of soil organic matter fractions different in solubility originating from a long-term field experiment. Geoderma 127(3-4): 196-206 https://doi.org/10.1016/j.geoderma.2004.12.002

Kaiser, E.A., T. Mueller, R.G. Joergensen, H. Insam, and O. Heinemeyer. 1992. Evaluation of methods to estimate the soil microbial biomass and the relationship with soil texture and organic matter. Soil Biology and Biochemistry 24: 675-683. https://doi.org/10.1016/0038$\underline{0717(92) 90046-Z}$

Klotz, I., R.H. Hurt, and E.M. Suuberg. 2004. Size distribution of unburned carbon in coal fly ash and its implications. Fuel 83(2): 223-230. https://doi.org/10.1016/S0016-2361(03)00255-2

Krzaklewski, W., M. Pająk, M. Pietrzykowski, and M. Strutyński. 2003. Possible applications of green alder (Alnusviridis (Charix) DC. And In Lam. \& DC.) in the reclamation of post-mining sites. Advances of Agricultural Sciences Problem Issues 493: 905-912 (In Polish, English summary). 
Krzaklewski, W., M. Pietrzykowski, and B. Woś. 2012. Survival and growth of alders (Alnusglutinosa (L.) Gaertn. and Alnusincana (L.) Moench) on fly ash technosols at different substrate improvement. Ecological Engineering 49: 35-40. https://doi.org/10.1016/j.ecoleng.2012.08.026

Kuznetsova, T., A. Lukjanova, M. Mandre, and K. Lõhmus. 2011. Aboveground biomass and nutrient accumulation dynamics in young black alder, silver birch and Scots pine plantations on reclaimed oil shale mining areas in Estonia. Forest Ecology and Management 262: 56-64. https://doi.org/10.1016/j.foreco.2010.09.030

McBride, M. 1994. Environmental chemistry of soils. Oxford University Press, NY.

Mitchell, J.S. and R.W. Ruess.2009. $\mathrm{N}_{2}$ fixing alder (Alnus viridis spp. fruticosa) effects on soil properties across a secondary successional chrono-sequence in interior Alaska. Biogeochemistry 95:215-229. https://doi.org/10.1007/s10533-009-9332-x

Lõhmus, K., A. Kull, J. Truu, M. Truu, E. Kaar, I. Ostonen, S. Meel, T. Kuznetsova, K. Rosenvald, V. Uri, V. Kurvits, and Ü. Mander. 2007. The reclamation of the North Estonian oil shale mining area. p. 387-401.In: Ü. Mander et al. (ed.). Springer. https://doi.org/10.1007/978-3-540$\underline{36763-524}$

Ostrowska, S., Z. Gawlinski, and Z. Szczubialka. 1991. Procedures for soil and plants analysis. Warsaw: Institute of Environmental Protection (In polish)

Orzeł, S., M. Forgiel, J. Socha, and W. Ochał. 2005. Biomass and annual production of common alder stand of the Niepołomice Forest. Electronic Journal of Polish Agricultural Universities 8: \#25. Available Online: http://www.ejpau.media.pl/volume8/issue1/art-25.html

Pandey, V.C. 2015. Assisted phytoremediation of fly ash dumps through naturally colonized plants. Ecological Engineering 82:1-5. https://doi.org/10.1016/j.ecoleng.2015.04.002

Pandey, V.C. and B. Singh. 2012. Rehabilitation of coal fly ash basins: Current need to use ecological engineering. Ecological 190-192. https://doi.org/10.1016/j.ecoleng.2012.08.037

Pandey, V.C., P.C. Abhilash, and N. Singh. 2009. The Indian perspective of utilizing fly ash in phytoremediation, phytomanagement and biomass production. Journal of Environmental Management 90: 2943-2958. https://doi.org/10.1016/j.jenvman.2009.05.001 
Pawłowski, S., K. Pawłowska, and B. Kubica. 1985. Geology of the Tamobrzeg native sulphur deposit (in Polish with English summary). Pr lnst Geol 114, Warsaw.

Pietrzykowski, M. 2015. Tree response to soil reconstruction on reclaimed post-mining sites - a key issue in forest ecosystem restoration. Chapter 1. p. 15-39 In: S. Orzeł S. (ed.), Agricultural University of Krakow Publishing, Krakow, Poland.

Pietrzykowski, M., W. Krzaklewski, and G. Gaik. 2010. Assessment of forest growth with plantings dominated by Scots pine (Pinussylvestris L.) on experimental plots on a fly ash disposal site at the Bełchatów power plant. University of Zielona Góra Scientifical Reports, Environmental Engineering 137: 65-74 (in Polish, English summary)

Pietrzykowski, M., W. Krzaklewski, and B. Woś. 2015. Preliminary assessment of growth and survival of green alder (Alnusviridis), a potential biological stabilizer on fly ash disposal sites. Journal of Forestry Research 26: 131-136. https://doi.org/10.1007/s11676-015-0016-1

Resh, S.C., D. Binkley, and J.A. Parrotta. 2002. Greater soil carbon sequestration under Nitrogenfixing trees compared with Eucalyptus species. Ecosystems 5: 217-231. https://doi.org/10.1007/s10021-001-0067-3

Socha, J. 2008. Effect of topography and geology on the site index of Piceaabies in the West Carpathian, Poland. Scandinavian Journal of Forest Research 23: 203-213. https://doi.org/10.1080/02827580802037901

Soil Science Division Staff. 2017. Soil survey manual. C. Ditzler et al. (ed.). USDA Handbook 18. Government Printing Office, Washington, D.C

Šourková, M., J. Frouz, and H. Šantrùčková. 2005. Accumulation of carbon, nitrogen and phosphorus during soil formation on alder spoil heaps after brown-coal mining, near Sokolov (Czech Republic). Geoderma124: 203-214. https://doi.org/10.1016/j.geoderma.2004.05.001

StatSoft Inc. 1984-2016. STATISTICA (data analysis software system), version 12.

Uri, V., J. Aosaar, M. Varik, H. Becker, K. Ligi, A. Padari, A. Kanal, and K. Lõhmus. 2014. The dynamics of biomass production, carbon and nitrogen accumulation in grey alder (Alnusincana (L.) Moench) chronosequence stands in Estonia. Forest Ecology and Management 327: 106117. https://doi.org/10.1016/j.foreco.2014.04.040 
Uzarowicz, Ł., Z. Zagórski, E. Mendak, P. Bartmiński, E. Szara, M. Kondras, L. Oktaba, A. Turek, and R. Rogoziński. 2017. Technogenic soils (Technosols) developed from fly ash and bottom ash from thermal power stations combusting bituminous coal and lignite. Part I. Properties, classification, and indicators of early pedogenesis. CATENA 157: 75-89. https://doi.org/10.1016/j.catena.2017.05.010

Van Miegroet, H. and D.W. Cole. 1984. The impact of nitrification on soil acidification and cation leaching in a red alder ecosystem. Journal of Environmental Quality 13: 586-590. https://doi.org/10.2134/jeq1984.00472425001300040015x

van Reeuwijk, L.P. 2002. Procedures for soil analysis. International Soil Reference and Information Centre. Food and Agriculture Organization of the United Nations.

Woś, A. 1999. Polish Climate. PWN, Warsaw (in Polish).

Wysocki, W. 1979. Reclamation of alkaline ash piles and protection of their environment against dusting. Industrial Environmental Laboratory Office of Research and Development U.S. Environmental Protection Agency Cincinnati, Ohio.

Zeide, B. 2005. How to measure stand density. Trees19: 1-14. https://doi.org/10.1007/s00468-004$\underline{0343-x}$

Żołnierz, L., J. Weber, M. Gilewska, S. Strączyńska, and D. Pruchniewicz. 2016. The spontaneous development of understory vegetation on reclaimed and afforested post-mine excavation filled with fly ash. CATENA 136: 84-90. https://doi.org/10.1016/j.catena.2015.07.013 